Purdue University

Purdue e-Pubs

Purdue CIBER Working Papers

Krannert Graduate School of Management

$1-1-2013$

\title{
Insider Trading Restrictions and Top Executive Compensation
}

David J. Denis

University of Pittsburgh - Main Campus, djdenis@katz.pitt.edu

Jin Xu

Purdue University, xu68@purdue.edu

Follow this and additional works at: http:// docs.lib.purdue.edu/ciberwp

Part of the Administrative Law Commons, Business Law, Public Responsibility, and Ethics Commons, Corporate Finance Commons, and the Finance and Financial Management Commons

Denis, David J. and Xu, Jin, "Insider Trading Restrictions and Top Executive Compensation" (2013). Purdue CIBER Working Papers. Paper 147.

http://docs.lib.purdue.edu/ciberwp/147

This document has been made available through Purdue e-Pubs, a service of the Purdue University Libraries. Please contact epubs@purdue.edu for additional information. 


\title{
Insider Trading Restrictions and Top Executive Compensation
}

\author{
David Denis \\ University of Pittsburgh \\ Jin Xu \\ Purdue University
}

CIBER Working Paper Series

2013-001 


\title{
Insider Trading Restrictions and Top Executive Compensation
}

\author{
David J. Denis ${ }^{*}$ and Jin $\mathrm{Xu}^{* *}$
}

April 2013

\footnotetext{
* Katz Graduate School of Business, University of Pittsburgh, Pittsburgh, PA 15260, U.S. A. djdenis@katz.pitt.edu.

**Krannert School of Management, Purdue University, 403 West State Street, West Lafayette, IN 47907-2056,

U.S.A.xu68@purdue.edu.
}

\begin{abstract}
We thank an anonymous referee, Leonce Bargeron, John Core (the editor), Melanie Cao, Martijn Cremers, Diane Denis, Mara Faccio, Steve Kaplan, Seoyoung Kim, Ken Lehn, David Lesmond, Tim Loughran, Henry Manne, John McConnell, Darren Roulstone, Shawn Thomas, and Mark Walker for helpful discussions and comments. In addition, the paper has benefited from comments from workshop participants at Carnegie Mellon University, Hong Kong University of Science and Techonology, Michigan State University, Nanyang Technological University, National University of Singapore, Penn State University, Singapore Management University, Temple University, Tulane University, University of Toronto, the 2009 Northern Finance Association meetings, the 2009 State of Indiana Finance Conference and the 2010 American Finance Association meetings for their helpful comments. Xu acknowledges the financial support from the Purdue University Center for International Business Education and Research. Special thanks are due to Luis Marques for part of the data used in the paper. Clarke Bjarnason provided able research assistance.
\end{abstract}




\title{
Insider Trading Restrictions and Top Executive Compensation
}

\begin{abstract}
The use of equity incentives is significantly greater in countries with stronger insider trading restrictions, and these higher incentives are associated with higher total pay. These findings are robust to alternative definitions of insider trading restrictions and enforcement, and to panel regressions with country fixed effects. We also find significant increases in top executive pay and the use of equity-based incentives in the period immediately following the initial enforcement of insider trading laws. We conclude that insider trading laws are one channel through which cross-country differences in pay practices can be explained.
\end{abstract}

JEL Classification: G18, G32, G34

Keywords: Insider trading restrictions, executive compensation, insider ownership 


\section{Insider Trading Restrictions and Top Executive Compensation}

\section{Introduction}

Recent studies document substantial cross-country variation in both the level of executive compensation and the use of equity-based incentives for top executives [see, e.g., Murphy (1999), Murphy (2012)]. However, the underlying factors contributing to these observed differences remain the topic of active investigation. For example, although Conyon, Core, and Guay (2011) find that higher levels of pay for U.S. CEOs relative to their U.K. and E.U. counterparts can be explained (at least in part) by their higher stock and option incentives, their findings leave open the question of why incentives are so much higher for U.S. CEOs. Indeed, Conyon et al. suggest that "researchers should shift their efforts toward better understanding the reason for differences in incentives between CEOs in the U.S. and CEOs in the U.K. and other parts of the world.”

We analyze whether country-level restrictions in insider trading contribute to crosscountry differences in top executive compensation. Specifically, we analyze several (not mutually exclusive) channels through which compensation and insider trading restrictions might be related. One possibility is that insider trading represents a form of compensation for top executives. Thus, when insider trading laws are restrictive, equilibrium in the labor market forces firms to increase the level of top executive compensation. A second possibility is that the strength of insider trading laws affects the optimal use of equity incentives. If insider trading

represents a form of equity incentives [e.g., Manne (1966)], restricting such trading might lead firms to substitute other types of equity incentives in the executive compensation contract. Similarly, when insider trading laws are weaker, firms might choose to use relatively fewer incentives in pay packages so as to avoid trading-related agency conflicts [see, for example, 
Baiman and Verrecchia (1995)]. Because greater equity incentives expose top executives to greater risk, the increased use of equity incentives when insider trading is restricted also leads to higher levels of compensation. A third possibility is that insider trading laws are themselves a response to cross-country differences in pay practices. Specifically, in countries in which firms use greater equity incentives, stronger insider trading laws are required to mitigate tradingrelated agency conflicts with executives.

To provide evidence on these hypotheses, we analyze both levels of top executive compensation and the use of equity-based incentives for a broad set of executives in 41 different countries. Our primary sample consists of 468 non-U.S. firms with American Depository Receipts (ADRs) and 1,852 U.S. firms in 2006. The primary virtue of analyzing compensation in foreign firms with ADRs is that such firms are required to file Form 20-F with the SEC. Thus, we are able to obtain complete, standardized compensation data at the firm level for all of our sample firms. By contrast, most prior cross-country compensation studies have been forced to rely upon survey-based and country-aggregate compensation data. ${ }^{1}$ We recognize that a possible limitation of our data is that firms with ADRs are not representative of the population of firms in that country and later address this potential limitation.

We measure insider trading restrictions in two ways. First, following Du and Wei (2004), we use an insider trading restriction (ITR) index that is based on global executive opinion surveys about the extent of insider trading restrictions in individual countries. Second, we use an insider trading law (ITL) index from Beny (2006) that captures differences in the strength of insider trading laws. Importantly, for our purposes, both ITR and ITL exhibit substantial cross-country variation.

\footnotetext{
${ }^{1}$ Examples include Abowd and Bognanno (1995), Abowd and Kaplan (1999), and Murphy (1999) who rely on Towers Perrin's Worldwide Total Remuneration reports.
} 
Our baseline analysis indicates that equity incentives are positively related to insider trading restrictions. These findings are robust to the inclusion of a variety of firm-level and country-level control variables, such as firm size, leverage, R\&D, growth opportunities, board structure, shareholder protection, and country GDP. Moreover, the implied impact of insider trading restrictions on equity incentives is also economically important. A one unit increase in the ITR index (approximately one standard deviation) is associated with an increase in overall equity incentives of over $200 \%$, and an increase in the percentage of equity-based pay (i.e., the incremental flow of incentives) of about twenty-two percentage points. We also find that the level of top executive total pay is positively associated with insider trading restrictions. However, we cannot reject that this finding is driven by the greater use of equity incentives (and, therefore, higher risk premium) in countries with stronger insider trading restrictions.

These baseline findings are consistent with all three hypothesized channels for the association between insider trading restrictions and compensation. In addition, a fourth possibility is that there is no causal connection between insider trading restrictions and top executive pay/incentives. Under this explanation, the association between the two is a spurious byproduct of the fact that our regressions omit potentially important factors that are correlated with both insider trading restrictions and executive pay.

To further discriminate among these alternative explanations, therefore, we conduct several additional tests. First, we exploit time-series variation in insider trading restrictions to estimate panel regressions with country and year fixed effects. The results from these tests indicate that greater restrictions on insider trading are associated with significant increases in the use of incentive compensation. 
Second, we analyze changes in compensation around the dates of initial enforcement of insider trading laws. After controlling for time trends and fixed country effects, we find that both the level of total executive compensation and the use of equity-based incentives increase significantly following the initial enforcement of insider trading laws.

Third, we analyze whether the observed link between executive compensation and insider trading restrictions is associated with the level of insider ownership. Because higher insider ownership diminishes the need for additional incentives at the margin, this should weaken the link between insider trading restrictions and the use of equity incentives if the direction of causation runs from trading restrictions to executive pay. Consistent with this argument, the results from these tests indicate that higher inside ownership weakens the link between insider trading restrictions and both overall equity incentives and the level of pay.

Based on the results of these additional tests, we conclude that the evidence appears most consistent with a causal link that runs from insider trading restrictions to compensation incentives. Such a link is consistent with both (i) insider trading serving as an implicit form of compensation, and (ii) firms optimally choosing to use greater (fewer) equity incentives when insider trading restrictions are strong (weak). Because (i) depends on insider trading restrictions leading to reduced trading profits for executives whereas (ii) does not, distinguishing between these two explanations requires observation of whether stronger insider trading restrictions actually do reduce executive trading profits.

Unfortunately, we are unaware of systematic data on the profitability of insider trading outside of the U.S. Therefore, we conduct an indirect test by analyzing the run-up in stock prices prior to acquisition announcements in each of our sample countries. Prior studies document both the existence of abnormal insider trading by executives prior to takeover announcements 
[Agrawal and Nasser (2012)] and an association between pre-announcement run-ups and informed trading [Arshadi and Eyssell (1991)]. We thus test whether cross-country differences in stock price run-ups are associated with the strength of insider trading laws. Consistent with reduced informed trading in countries with tighter restrictions on insider trading, we find a significant negative association between pre-acquisition stock price run-ups and the strength of insider trading restrictions. However, we note an important caveat with interpreting this finding as evidence of reduced insider profits for executives in countries with stronger insider trading restrictions. Although the study by Arshadi and Eyssell (1991) finds that there is a reduction in net insider purchases prior to tender offer announcements after the passage of a new insider trading law in the U.S., they report that the largest effect is on trading by beneficial owners of the target's shares. Thus, our finding of lower run-ups in countries with stronger insider trading restrictions can be viewed as evidence of reduced trading profits for executives only if the trades of those executives are correlated with those of other beneficial owners. Unfortunately, we lack direct evidence on that issue.

By identifying insider trading restrictions as an important channel through which differences in cross-country compensation and incentives can be explained, our findings contribute to the growing international executive compensation literature. ${ }^{2}$ Our findings also complement and extend those of Roulstone (2003), who finds that self-imposed insider trading restrictions in U.S. firms are related to higher executive compensation and a greater level of incentive compensation.

The remainder of the paper is organized as follows. In Section 2, we provide background on the literature that hypothesizes a link between insider trading and compensation. Section 3

\footnotetext{
${ }^{2}$ See also Abowd and Bognanno (1995), Conyon and Schwalbach (1997), and Fernandes, Ferreira, Matos, and Murphy (2012).
} 
describes our sample selection process and describes our primary data. Section 4 reports the results of our cross-sectional regressions. In Section 5, we report the results from a series of additional tests that explore alternative explanations for our findings. Section 6 reports the results from our analysis of stock price run-ups prior to acquisition announcements and Section 7 concludes.

\section{Insider Trading, Equity Incentives and Top Executive Compensation}

In this section, we discuss several channels through which insider trading restrictions might be associated with compensation levels and equity incentives. These channels differ in the extent to which they rely on a substitution between insider trading profits and compensation, and the direction of causation in the hypothesized association between insider trading restrictions and compensation.

\subsection{Compensation and insider trading profits as substitutes}

A large body of academic literature reports that insider trading allows insiders to profitably exploit their private information and realize significant trading profits. ${ }^{3}$ Several studies point to such trading profits as providing a potential link between insider trading restrictions and compensation policies. In Baiman and Verrecchia (1995, 1996), managers can trade profitably based on their private information, but shareholders compute the expected amount of this redistribution from traders and deduct it from explicit managerial pay. If equilibrium wages are determined competitively and the level of compensation is measured as

\footnotetext{
${ }^{3}$ See, for example, Damodaran and Liu (2003), Fidrmuc, Goergen, and Renneboog (2006), Meulbroek (1992), and Seyhun (1986).
} 
the sum of explicit compensation and insider trading profits, these models predict a positive association between insider trading restrictions and equilibrium compensation levels. ${ }^{4}$

Other studies point towards insider trading profits as a substitute source of equity incentives. For example, both Carlton and Fischel (1983) and Manne (1966) hypothesize that because insider trading allows insiders to profit from their innovation and effort, it represents a means for providing incentives to top executives. Moreover, Carlton and Fischel (1983) argue that allowing insider trading is more efficient than ex post salary renegotiations of the type in Fama (1980) because it avoids frequent and costly renegotiations. Thus, if insider trading is restricted, firms need to make greater use of other forms of incentive compensation in order to maintain optimal incentive levels. The greater use of incentives in turn, leads to higher levels of compensation as executives are compensated for bearing greater risk.

Although the above arguments suggest that restrictions on insider trading will lead firms to substitute into other forms of equity incentives, critics argue that insider trading can create perverse incentives as well. For example, several studies point out that because insider trading allows executives to profit from bad news as well as good news, managers may be less willing to exert effort to increase firm value, and may even take actions that create unfavorable news. ${ }^{5}$ This argument suggests that when insider trading is allowed, firms should make greater use of incentive compensation in order to counteract the perverse incentive effects of insider trading.

\footnotetext{
${ }^{4}$ A similar argument is also made by Khanna, Slezak and Bradley (1994).

${ }^{5}$ See, for example, Bagnoli and Khanna (1992), Levmore (1992), and Schotland (1967). Carlton and Fischel (1983) contend that these adverse incentive effects of insider trading are of second-order importance because of limits on short-selling as well as reputation and litigation concerns.
} 


\subsection{Insider trading restrictions and the optimal use of incentives}

The predictions outlined above rely on a substitution between executive trading profits and top executive compensation. Similar predictions can be obtained, however, even if there is no such substitution. For example, Baiman and Verrecchia (1995) model two types of agency problems related to informed trading by managers in their own shares. In the first, the ability of managers to trade in their own shares weakens the link between compensation paid by shareholders and the consumption of managers. This reduces shareholder control over the manager's effort decision thereby diminishing the usefulness of equity incentives. In the second, managers trading in their own shares can affect the market price of those shares and, consequently, their level of compensation. Shareholders will optimally account for this potential for manipulation by lowering the weight on stock price in the manager's compensation contract. ${ }^{6}$

Thus, even if there is no substitution between insider trading profits and explicit compensation, these arguments predict a positive association between country-level insider trading restrictions and equity incentives. Again, executives of firms using greater equity incentives will require higher levels of total pay as compensation for bearing greater incentive risk. These arguments therefore also predict a positive association between country-level insider trading restrictions and the level of compensation.

\subsection{Insider trading laws as an endogenous response to country pay practices}

Although the above hypotheses predict a causal association that runs from insider trading restrictions to equilibrium compensation incentives, it is possible that the direction of causation

\footnotetext{
${ }^{6}$ Note that alternatively, shareholders could impose their own restrictions on executive trading through more stringent vesting requirements, as well as restrictions on option exercises and stock sales. Thus, this hypothesis implicitly assumes that the costs of imposing and enforcing such firm-specific restrictions exceed the benefits of doing so.
} 
is reversed. That is, country-level insider trading laws themselves might be an endogenous response to typical pay practices within that country. For example, in countries that make greater use of equity incentives in compensation plans, regulators might set tighter insider trading restrictions to mitigate trading-related agency conflicts of the type described in Baiman and Verrecchia (1995, 1996). Again, compensation levels will necessarily be higher in these countries to compensate executives for bearing greater incentive risk.

\subsection{Related evidence}

There are thus several plausible reasons to expect a positive association between countrylevel insider trading restrictions and both compensation levels and the use of incentives. The existence of such an association and its underlying reasons are empirical issues that our study addresses. To date, the literature provides only limited, indirect evidence. Roulstone (2003) studies the link between compensation and self-imposed insider trading restrictions. He finds that firms with such restrictions exhibit higher levels of compensation and make greater use of incentive compensation. Although Roulstone interprets these findings as consistent with the view that insider trading plays a role in rewarding and motivating employees, it is difficult to rule out the possibility of a correlated omitted variable. Moreover, because Roulstone (2003) analyzes insider trading restrictions and compensation in just one country, the U.S., his study does not address whether cross-country differences in compensation practices are associated with country-level restrictions on insider trading. Our study aims to fill this gap by providing direct evidence on the association between insider trading restrictions and executive compensation in a cross-country setting. ${ }^{7}$

\footnotetext{
${ }^{7}$ Baiman and Verrecchia (1996) also suggest that the analysis of international data could be useful for addressing whether higher levels of executive compensation in the U.S. is related to differences in insider trading: "The greater
} 


\section{Sample Selection and Data Description}

In this section, we describe the executive compensation data that we use in our empirical analysis as well as our primary measures of insider trading restrictions. We then report summary statistics for the sample.

\subsection{Executive Compensation Data}

Foreign companies issuing ADRs in the U.S. markets are required to file Form 20-F reports with the Securities and Exchange Commission (SEC). This form contains information on the board of directors, the compensation of executives and directors, the location of the business, the company's industry sector, and other miscellaneous items. ${ }^{8}$ From the 20-F reports, we collect compensation data for the top executives of all foreign firms issuing ADRs. Compensation data for executives of U.S. firms is obtained from ExecuComp.

We begin with a list of all Level 2 and Level 3 ADRs as of May 2008 from the JPMorgan ADR Group website. We then supplement this set of firms by examining the list of all ADRs from 1961 to 2007 downloaded from CRSP. We exclude Level 1 and Rule 144A ADRs because they are either traded over the counter or are private placements, making them exempt from SEC reporting requirements. For the resulting set of ADRs, we search SEC's EDGAR database for 20-F filings in 2006. If a sample firm does not have a 20-F filing in 2006, we obtain the relevant data from either its 2005 or 2007 filing, where available.

There is some variation in the level of detail with which executive compensation data is available. In some filings, information on compensation of individual executives (typically the

diffuseness of U.S. capital markets and the consequent less profitable opportunities for insider trading by managers may provide a partial explanation for the observed higher level of direct compensation received by U.S. CEOs.” (p. 2-3).

${ }^{8}$ See Bryan, Nash and Patel (2006) for a detailed description of this source of compensation data. 
most highly-paid executives) can be obtained from summary executive compensation tables. We later refer to these firms as U.S. style reporting firms. In other cases, the compensation tables report only the aggregate compensation for all executives (and directors). For each firm, we construct firm-level compensation variables that capture the level and structure of compensation for the average executive in that firm. Whenever available, we use the individual executive-level data to construct our firm-level measures. Otherwise, we use the aggregate firm-level data to construct average values per top executive.

The compensation data contain various components: salary, bonus, equity-based compensation such as restricted stock awards and option grants, and other compensation such as pensions and perquisites. Our analysis focuses primarily on the dollar amount of total compensation (Total Pay) and a measure of overall equity incentives (Equity Incentives). Total Pay is defined as the sum of salary, bonus, equity incentive compensation (including restricted stock awards and option grants) and other compensation. ${ }^{9}$ When stated in local currencies, Total Pay is converted into U.S. dollars using year-average exchange rates in corresponding data years as the conversion rate. In addition, all Total Pay figures are converted into 2006 real dollars by adjusting for the inflation rate between 2006 and the given year. Equity Incentives are measured as the overall sensitivity of executive wealth to a $1 \%$ change in the firm's stock price. Because this measure requires data at the individual executive level, tests using this measure are conducted on the subset of firms with U.S. style reporting. Nonetheless, because we do not have complete data on the details of outstanding options (e.g., maturity, exercise price, etc.), these sensitivities are estimated based on fully diluted shares outstanding; i.e., assuming that all outstanding options are exercised. Finally, in some tests, we use a measure of the incremental

\footnotetext{
${ }^{9}$ For both restricted stock awards and option grants, we use the grant's market value at the time of the award. The grant date fair value of options granted is used in the calculation, which is largely made available in the 20-F, following the International Financial Reporting Standards 2 (IFRS2).
} 
flow of incentives (Equity Pay Ratio) - defined as the fraction of total compensation that is comprised of equity-based incentive pay, where equity-based incentive pay is measured as the total grant-date value of restricted stock awards and option grants. The definitions for these and other variables can be found in Appendix A.

A possible concern with our sample is that, because the ADR firms are listed in the U.S., the insider trading restrictions that apply to them are different from those that apply to the general population of firms in their home country. For example, perhaps by listing in the U.S., ADR firms are subject to U.S. insider trading regulation. However, because of the SEC's longstanding policy goal of facilitating access of foreign issuers to U.S. capital markets, ADR firms are provided with a variety of exemptions to U.S. insider trading rules. For example, the Exchange Act Rule 3a12-3(b) ${ }^{10}$ exempts foreign private issuers from the Commission's proxy rules $^{11}$, and from the insider stock trading reports and short-swing profit recovery provisions under Section $16^{12}$ of the Exchange Act. ${ }^{13}$ Regulation FD, which limits private communications of material information, also exempts foreign private issuers from its coverage. ${ }^{14}$ Foreign private issuers would be subject to the pension blackout trading restriction (Regulation BTR), a clarification to Section 306(a) of the Sarbanes-Oxley Act of 2002, but only under a certain condition. ${ }^{15}$ Thus, ADR firms are not subject to the same level of insider trading regulation as

\footnotetext{
${ }^{10}$ Also referred to as 17 CFR 240.3a12-3(b).

${ }^{11} 17$ CFR 240.14a-1 et seq.

1215 U.S.C. 78p.

${ }^{13}$ See, for example, Ownership Reports and Trading by Officers, Directors and Principal Security Holders, RIN 3235-AI62, Final Rule, Securities and Exchange Commission, footnote 12. Alternatively, see Foreign Issuer Reporting Enhancements, RIN 3235-AK03, Final Rule, Securities and Exchange Commission, footnote 37.

${ }^{14}$ Selective Disclosure and Insider Trading, RIN 3235-AH82, Final Rule, Securities and Exchange Commission.

${ }^{15}$ Insider Trades During Pension Fund Blackout Periods, RIN 3235-AI71, Final Rule, Securities and Exchange Commission. According to the rule, foreign private issuers are only subject to Reg BTR if the blackout were to
} 
U.S. firms. Moreover, because the majority of ADR firms are also listed on their domestic exchange, they are required to follow domestic insider trading laws. Finally, even if ADR firms are affected primarily by U.S. insider law and enforcement, this will bias our tests against finding any association between compensation and our measures of insider trading restrictions.

A related concern is that because ADR firms tend to be larger and more profitable than the typical firm in their home country, our findings are subject to a sample selection bias. It is important to point out, however, that any such selection bias applies to all of the countries that make up our sample. Thus, it is unlikely to bias our estimates of the cross-sectional association between compensation and insider trading restrictions.

Nonetheless, to provide further evidence on this issue, we compare our data with the summary compensation data from Fernandes, Ferreira, Matos, and Murphy (2012). For the twenty-three countries that are common to both studies, our compensation measures, Total Pay and Equity Pay Ratio, both have correlation coefficients of around 0.55 (significant at the 1\% level) with similar measures in Fernandes et al. (2012). These high correlations imply that, despite potential differences between ADR firms and their local counterparts, the cross-sectional variation in pay practices among ADR firms is similar to that among local firms. Moreover, within the empirical analyses, we control for firm characteristics such as firm size, profitability, market-to-book ratio, financial leverage, board size and board independence to account for differences in these characteristics across firms. Finally, in addition to the ADR compensation data, we later report robustness tests that utilize alternative data sources.

affect at least $50 \%$ of the pension plan beneficiaries located within the U. S. and such persons represented more than $15 \%$ of all participants and beneficiaries under all individual account plans of the issuer. 


\subsection{Insider Trading Measures}

Our primary measure of insider trading restrictions comes from the 1999 Global Competitiveness Report. This Report records responses from approximately 4,000 executives in 59 countries to the following survey question regarding the likelihood of insider trading in their respective countries:

\subsection{5 [Insider trading] Insider trading is not common in the domestic market $(1=$ strongly} disagree, 7=strongly agree)

We record the average score for all executive responses in a given country and use this as that country's Insider Trading Restriction (ITR) index. Larger values of ITR correspond with a more restrictive insider trading environment in that country. ${ }^{16}$

To supplement the survey-based insider trading measure, we also construct an alternative measure based exclusively on countries’ statutory insider trading laws. Specifically, the Insider Trading Law (ITL) index is the sum of three binary variables, Tippee, Tipping and Criminal, compiled by Beny (2004, 2006). These three variables represent the primary elements of the law. Tippee equals 1 if tippees (i.e., a corporate outsider receiving inside information from an insider) are subject to insider trading regulation and 0 otherwise. Tipping equals 1 if an insider can be held liable for tipping outsiders and 0 otherwise. Criminal is 1 if violation of the insider trading law is a criminal offense and 0 otherwise. The ITL index is available for thirty-three of the forty-one countries in the sample.

\footnotetext{
${ }^{16}$ This index is also available in years 1996 and 1998. We use the most recent year's index as the insider trading restriction index, though our results do not change if other years' indices or their average are used. Note that there is a seven-year lag between the measurement of ITR and the measurement of our compensation variables. Thus, it is possible that during the intervening seven years, countries could initiate changes in insider trading laws. If so, this additional noise in the data will bias our tests against finding any association between insider trading restrictions and executive compensation. We later construct and examine panel datasets in which compensation and insider trading are measured in adjacent years.
} 
Because ITR has the potential to capture the joint impact of insider trading laws, their enforcement, and other factors such as culture and information environment, it is arguably a more complete measure of insider trading restrictions than ITL. However, because ITR is based on survey data, it is subject to biases related to the subjective judgments of the responders. Our ITL measure, therefore, provides a useful robustness check. In later tests, we provide another robustness test that makes use of dates of initial prosecution under insider trading laws.

\subsection{Summary Statistics}

Panel A of Table 1 reports the sample distribution by country, as well as summary measures of each country's insider trading restrictions. Our international data consists of 468 ADR firms from forty different countries for the year 2006, which we supplement with 1,852 U.S. firms in the 2006 dataset. On average, there are 12 ADR firms in each country. However, this average masks considerable variation across countries. Several countries (e.g., Brazil, China, and the U.K.) have more than 30 firms while others (e.g., Austria, Belgium, Colombia, Hungary, Turkey and Venezuela) have just one observation.

The data in Panel A also indicate that there is substantial cross-country variation in the degree of insider trading restrictions. The ITR index ranges from 3.18 (Taiwan) to 6.22 (Luxembourg) with an average of 4.48 and a standard deviation of 0.91 . The ITL index varies between 1 and 3 with an average of 2.5. As of 2006, insider trading laws had been in existence for an average of 20 years (2006 minus 1986) and had been enforced for an average of 15 years (2006 minus 1991). Interestingly, some countries have never enforced existing insider trading legislation (e.g. China, Colombia) while others have had a long history of enforcement (e.g. France, U.S.). 
Consistent with common perception, the U.S. appears to have among the most restrictive insider trading laws, with an ITR index of 5.64 (only Luxembourg and the UK are higher). At the other end of the spectrum is Mexico with an ITR of 3.54, ITL of 1, and no evidence that its existing laws have ever been enforced.

Finally, the bottom row of Panel A shows that our survey based measure of insider trading restrictions, ITR, is significantly positively correlated with ITL ( $\rho=0.58)$, and negatively related to the year in which IT laws first came into existence and the year in of initial IT law enforcement. This implies that corporate executives perceive insider trading as being more restricted in countries with stricter insider trading laws and where insider trading laws have existed or have been enforced for a longer time.

Panel B of Table 1 provides summary statistics for our compensation variables, as well as several firm and country-level control variables. We partition the sample into those firms with ITR below the median (4.37) and those above the median and report the significance of the difference in average values. We find that firms in countries with stronger insider trading restrictions are characterized by higher total pay. Specifically, total pay averages just under \$300,000 US dollars for firms with below median ITR and over \$1.6 million for firms with ITR greater than median. Equity incentives (as measured by the sensitivity of executive wealth to a $1 \%$ change in stock price) are not significantly different between low-ITR firms and high-ITR firms.

In addition, we report significant differences in firm and country characteristics between the sub-samples of high-ITR and low-ITR firms. Firms from countries with greater insider trading restrictions are characterized by lower profitability and percentage insider ownership, and higher board independence and R\&D expenditures. In addition, we find that countries with 
stronger insider trading restrictions have higher GDP per capita and greater stock market development (as measured by the ratio of stock market capitalization to GDP). We later control for these firm and country-level factors in our compensation regressions. ${ }^{17}$

\section{The Association between Insider Trading Restrictions and Executive Compensation}

In this section, we report our base analyses of the empirical association between insider trading restrictions and executive compensation using our sample of U.S. and ADR firms in 2006. We begin in Section 4.1 with the univariate association, and then estimate multivariate regressions of the association between insider trading restrictions and both compensation levels and incentives in Section 4.2.

\subsection{Univariate Analysis}

Figure 1 contains scatter plots of the univariate association between insider trading restrictions and top executive compensation/incentives. As depicted in Figure 1A, Total Pay is highest for U.S. firms and ADR firms from European countries. ${ }^{18}$ Within Europe, France, Germany, Switzerland and the U.K. pay relatively higher compensation than the rest of Europe. Pay levels are lowest in Peru, the Philippines and China. Notably, the scatter plot depicts a positive correlation between the level of executive pay and insider trading restriction: countries with high ITR exhibit higher compensation levels.

\footnotetext{
${ }^{17}$ In unreported results, we also find that U.S. firms exhibit some significant differences from ADR firms. Because U.S. firms substantially outnumber the ADR firms, we later test whether our findings are robust to the exclusion of U.S. firms.

${ }^{18}$ At first glance, it is surprising that the U.S. firms do not appear to pay much higher compensation than some European countries, given prior evidence (e.g., Murphy (1999)). However, European ADR firms tend to be larger, on average, than the typical U.S. firm. In the following multivariate analysis, we control for firm size and other firm characteristics and present results separately for ADR firms to avoid possible biases.
} 
Figure 1B depicts the univariate association between ITR and total Equity Incentives. The univariate association is positive. Those countries with stronger insider trading restrictions (e.g. U.S., U.K., Australia) tend to have greater equity incentives. Some countries (e.g. China and India) are notable outliers, however, in that they exhibit very high equity incentives with few country-level restrictions on insider trading.

Finally, Figure 1C depicts the association between ITR and the Equity Pay Ratio. Consistent with prior literature, the U.S. and the U.K. are among the countries paying the highest fractions of equity-based compensation (34\%-35\%). Finland and China also stand out as countries using the most equity-based compensation. At the other end of the spectrum, several countries make no use of equity based compensation at all. Again, it is notable that there appears to be a strong positive correlation between the ITR index and the Equity Pay Ratio.

\subsection{Multivariate Regressions}

To provide more formal evidence, we estimate multivariate regressions in which the log of equity incentives, log of total compensation, and the equity pay ratio are the dependent variables. In each regression model, we control for several firm characteristics that have been shown in prior studies to be associated with compensation levels. These include the log of the book value of total assets, the market-to-book ratio, debt-to-asset ratio, return on assets (ROA), measured as the ratio of operating income before depreciation and amortization to lagged assets, lagged annual stock return, and the ratio of research and development expenditures (R\&D) to total assets. [See, e.g., Aboody and Lev (2000), Bizjak, Lemmon, and Naveen (2008), OrtizMolina (2007)]. In addition, because corporate governance has been shown to affect executive compensation [e.g., Chhaochharia and Grinstein (2009)], we include board size and board 
independence as independent variables. Finally, to control for country-level determinants of compensation, we include the logarithm of GDP per capita, the stock market capitalization-toGDP ratio, and the anti-director index. We include industry fixed effects at the 2 digit SIC level to control for unobserved industry-specific factors, and compute heteroskedasticity-robust standard errors that are clustered by country.

Equity Incentives. In Models (1) and (2) of Table 2, we test the association between the $\log$ of total equity incentives and insider trading restrictions. Because of the additional data requirements for computing equity incentives at the executive level, these tests are limited to the subsample of firms with U.S. style reporting. Also, because we observe a clustering of observations at zero, we estimate these models using a Tobit specification. These findings indicate that the level of equity incentives is positively related to both ITR and ITL. The impact of insider trading restrictions is both statistically significant and economically meaningful. A one-unit increase in ITR corresponds to an over $200 \%$ increase in total equity incentives (120\% for ITL). ${ }^{19}$ Consistent with prior literature [e.g., Baker, Jensen, and Murphy (1988) and Yermack (1995)], overall equity incentives are positively related to firm size and to the firm's market-to-book ratio. In addition, total incentives are positively related to stock returns and R\&D expenditures, and negatively related to leverage, per capita GDP, and the anti-director index. Total incentives are also greater for CEOs and for older executives.

Total Pay. In columns (3) and (4) of Table 2 we report results in which the log of total compensation is the dependent variable. We again report separate results for our two primary

\footnotetext{
${ }^{19}$ At first glance, the positive association between equity incentives and insider trading restrictions is puzzling in light of prior studies that report a negative association between insider ownership and the quality of a country's institutions. Note, however, that our equity incentives variable represents the dollar change per $1 \%$ change in equity value, while the insider ownership variable used in the literature is the percentage of shares owned by the insiders. The two variables are not highly correlated in our data $(\rho=0.09)$. Moreover, our regressions include a number of country variables that are meant to capture the general institutional setting of the country.
} 
measures of the restrictions on insider trading: the Insider Trading Restriction index (ITR) and the Insider Trading Law index (ITL). Because the firm-level total pay variable is derived from the reported aggregate compensation given to executive officers or officers and directors, we also include a dummy variable indicating whether the total pay figure involves non-executive directors. This controls for any systematic difference in pay between non-executive directors and executive officers.

The results in columns (3) and (4) indicate a significant association between insider trading restrictions and total compensation. The coefficient on insider trading restrictions is significantly positive using either ITR or ITL as the measure of insider trading restrictions. Moreover, the economic magnitude of the coefficient on insider trading restrictions is substantial. For example, the ITR coefficient of 0.385 in column (3) implies that an increase of one unit in ITR corresponds to a 38.5\% increase in Total Pay. Based on the full-sample mean value of the $\operatorname{Ln}$ (Total Pay) of 13.3 at the firm level, this change amounts to approximately $\$ 230,000$ (U.S.).

A positive association between insider trading restrictions and total compensation is consistent with two potential channels. First, it might reflect a substitution between insider trading profits and the level of compensation. Second, it might be the byproduct of differences in the use of incentives. That is, cross-country differences in the level of executive compensation might reflect increased risk premia resulting from differences in the use of equity incentives. To assess this possibility, we also control for equity incentives in the total pay regressions. Because the equity incentives variable is only available for the subsample of countries and firms with U.S. style reporting, we present the results separately in columns (5) and (6). We keep the compensation and incentive variables at the executive level and add an 
indicator for CEOs and executive age as controls. The results show a significantly positive correlation between equity incentives and total pay, consistent with Conyon et al. (2011). The coefficients on insider trading restrictions, though similar in magnitude to columns (3) and (4), become statistically insignificant. Thus, we cannot rule out that the observed association between insider trading restrictions and total pay is a byproduct of the relation between insider trading restrictions and equity incentives.

As for the control variables, consistent with prior literature, we find that level of pay is positively associated with firm size and information asymmetry (as measured by R\&D-to-assets). In addition, total pay is positively associated with GDP per capita and (in some specifications) with board independence and the market-to-book ratio. Not surprisingly, total pay is significantly lower if both executive officers and non-executive directors are included in firm aggregate total pay. At the executive level and in the subsample with U.S. style reporting, total pay is negatively related to financial leverage and positively related to ROA and stock returns. Total pay is also higher for the CEO and for older executives.

Equity Pay Ratio. Finally, Models (7)-(10) of Table 2 report the results of similar Tobit regressions in which we test the association between insider trading restrictions and equity incentive pay. Since the theory discussed earlier does not yield precise predictions about the association between insider trading restrictions and the flow of incentives, the results in Columns (7)-(10) should be viewed as descriptive.

The results indicate a significant positive association between insider trading restrictions and the proportion of equity-based incentive compensation. The coefficient on insider trading restrictions is statistically significant, regardless of whether ITR or ITL is used as the measure of insider trading restrictions. Moreover, the effect is economically large; a one-unit increase in 
ITR corresponds to a nearly 22 percentage point increase in the equity pay ratio (Model 5). This marginal impact is large relative to the unconditional average Equity Pay ratio of 0.17 . Moreover, including equity incentives as a control does not mitigate the statistical significance of the effect (columns 9-10).

Most control variables depict the same associations with Equity Pay Ratio as those with overall equity incentives except that firm performance (ROA and stock return) is negatively related to the equity pay ratio while positively related to overall equity incentives. In addition, board independence and stock market capitalization are positively related to the equity pay ratio while unrelated to total equity incentives.

\section{Additional Tests}

Our findings to this point indicate that equity incentives are positively related to insider trading restrictions. We also find that the level of top executive total pay is positively associated with insider trading restrictions. However, we cannot reject that this finding is driven by the greater use of equity incentives (and, therefore, higher risk premium) in countries with stronger insider trading restrictions.

These findings are consistent with several potential explanations. Compensation incentives might be determined by insider trading restrictions, either because firms view insider trading profits and direct incentives as substitutes, or because greater insider trading restrictions allow firms to optimally use more equity incentives. Alternatively, countries might respond to the greater use of equity incentives within their country by imposing stronger insider trading laws in order to mitigate trading-related agency conflicts with executives. Finally, it is possible that our baseline findings are spurious because insider trading restrictions are correlated with 
other country factors that have been omitted from our regression models. In this section, we conduct several additional tests to explore alternative explanations for our findings.

\subsection{Panel Data Analysis}

Our regression models omit country factors that are potentially correlated with both insider trading restrictions and compensation. As one approach to testing whether the exclusion of these factors influences our results, we exploit within-country, time-series variation in insider trading restrictions to provide further evidence on the link between insider trading restrictions and compensation. Recall that the ITR index is available from the Global Competitiveness Reports for three years: 1996, 1998 and 1999. Over these three years, some countries exhibit large changes in insider trading restrictions. For example, the ITR index for Italy is 2.92 in 1996, and then increases to 3.88 in 1998, and to 4.38 in 1999. Italy's increases in ITR occurred with its corporate governance law reform in early 1998 that strengthened insider trading regulation. ${ }^{20}$ These types of within-country changes allow for identification in panel regressions in which we include country fixed effects to capture any time-invariant country factors and year fixed effects to capture common macroeconomic influences on compensation.

Unfortunately, EDGAR contains relatively few 20-F reports in the 1990s making it difficult to achieve a sample size sufficiently large to estimate panel regressions. ${ }^{21}$ Therefore, we extract information on incentives from the Global Competitiveness Reports of 1996, 1998 and 1999. The 1996 survey asks about non-wage incentives: "Non-wage incentives (such as

\footnotetext{
${ }^{20}$ See Chapter IV, Unauthorized use of inside information and manipulation involving financial instruments, under Title I in Part V of the Italian Legislative decree 58 of 24 February 1998: Consolidated law on financial intermediation. Source: European Corporate Governance Institute.

${ }^{21}$ Specifically, our matching of the 20-F compensation data with the ITR index data yields only 88 ADR firms from 25 different countries.
} 
profit sharing and stock purchase plans) are used effectively to motivate employees (1=strongly disagree, 6=strongly agree)”. The 1998 and 1999 surveys both ask about performance pay: “Compensation policies link pay closely with job performance (1=strongly disagree, $7=$ =strongly agree)". Our operating assumption is that answers to these questions are correlated with the company's use of incentive compensation. This data is available for a broader set of countries, ranging from 49 in 1996 to 59 in 1999. Appendix B lists the ITR index for each country during the three years spanning our panel dataset.

Table 3 reports the results from two sets of regressions. In the first, we estimate regressions of the survey-based Incentive Pay Measure (IPM) on ITR, country GDP per capita and stock market capitalization to GDP. ${ }^{22}$ This first set of regressions contains both country and year fixed effects. In the second set of regressions, we estimate the association between annual changes in IPM and changes in ITR. Because these are change regressions, country fixed effects are not included. Note also that, because all variables are country level, no firm characteristics are included as controls.

The results in Columns (1)-(2) of Table 3 indicate that, controlling for country and year fixed effects, the incentive pay measure is significantly associated with insider trading restrictions. Moreover, as indicated in Columns (3)-(4), changes in the incentive pay measure are significantly associated with changes in insider trading restrictions. These findings provide further confidence that our main findings are not being driven by some correlated omitted variable at the country level. Taken at face value, the results imply that firms adjust the use of incentives in response to changes in their country's insider trading environment.

\footnotetext{
${ }^{22}$ Note that although our baseline regressions in Table 2 include the anti-director index, we exclude that index from our panel regressions because there is just one observation on the index for each country.
} 


\subsection{Evidence from Initial Enforcement of Insider Trading Laws}

Our findings establish an association between executive compensation and either perceptions of insider trading restrictions (ITR) or an index of the country's statutory restrictions (ITL). As shown in Table 1, however, countries differ in when they enforce the statutory insider trading laws in a court of law for the first time. Prior literature finds that the dates of initial enforcement mark meaningful changes in insider trading regimes around the world. That is, insider trading becomes more restricted following initial enforcement of insider trading laws [Bhattacharya and Daouk (2002), Bushman, Piotroski, and Smith (2005) and Bekaert, Harvey, and Lundblad (2001)]. Because the initial enforcement of insider trading laws represents a discrete change in insider trading restrictions, tests of changes in compensation in the period following the dates of initial enforcement can thus provide additional evidence of the link between insider trading restrictions and executive compensation.

Unfortunately, as noted earlier, compensation data from ADR 20-F reports is available for only a limited time period. Thus, for this analysis, we rely on the Worldwide Total Remuneration reports published by Towers Perrin for the executive pay data. This data covers 25 countries between 1994 and 2001 comprising 182 country-year observations, and contains information about total CEO pay and the Equity Pay Ratio. ${ }^{23}$ We construct an IT Enforce indicator variable that takes the value of 1 for the year of and years following the initial enforcement, and 0 otherwise. We then estimate panel regressions of total compensation and the equity pay ratio on IT Enforce and the country-level control variables (GDP per capita and stock market capitalization). In the total compensation regressions, we also include the equity pay ratio as an imperfect control for the possibility that executives demand a risk premium for

\footnotetext{
${ }^{23}$ Due to the limitations of the Towers Perrin data, we are unable to include a direct measure of total equity
} incentives. 
holding greater equity incentives. In these models, therefore, the coefficient on IT Enforce captures the differences in total compensation and the incremental flow of equity incentives between country-years prior to enforcement and country-years following enforcement of insider trading laws. ${ }^{24}$ Appendix $\mathrm{C}$ lists the availability of data for each country.

Panel A of Table 4 summarizes the variables for subsamples divided by IT Enforce. There are 43 pre-enforcement country-years and 139 post-enforcement country-years. Both total pay and the equity pay ratio are higher in the years following initial enforcement of insider trading laws. These differences are statistically significant at the 0.01 level using a two-sample t-test.

The increases in total pay and the equity pay ratio observed in Panel A can originate from three sources: (i) an increase following enforcement within the same country (the time series effect), (ii) a cross-sectional difference between enforced and non-enforced countries (the cross sectional effect), or (iii) a general increasing time trend independent of enforcement (the time trend). In the regression analysis, we include year dummy variables to eliminate the time trend. We also examine country-adjusted variables, which are constructed by subtracting country averages from the raw variables. For each raw variable, its country average is the average over all years for that country. ${ }^{25}$

Panel B of Table 4 reports the regression results. Columns (1) and (2) report results in which the log of total pay is the dependent variable, while columns (3) and (4) report results in which the equity pay ratio is the dependent variable. Tests based on the raw variables (columns 1 and 3) indicate that, controlling for GDP per capita and stock market capitalization, the equity

\footnotetext{
${ }^{24}$ Because there are only four country-years in the sample prior to the initial enactment of insider trading laws, we do not examine the initial enactment dates.

${ }^{25}$ Our estimation approach is nearly equivalent to estimating models including country fixed effects. The only difference is that fixed effects models effectively country-adjust all the independent variables, including the IT Enforce dummy variable, whereas in the models in Table 4, the dummy variable is not country-adjusted.
} 
pay ratio is significantly higher in the country-years after initial enforcement of insider trading laws. More importantly, Columns (2) and (4) indicate that both country-adjusted total pay and equity pay ratio are significantly larger following initial enforcement of insider trading laws (t statistics for the IT Enforce coefficients are 2.38 and 2.51, respectively). Within a country, total pay increases by an average of $13.6 \%$ and the fraction of equity incentive pay in total pay increases by 1.2 percentage points after initial insider trading law enforcement.

Overall, therefore, the findings in Table 4 provide support for the view that following initial enforcement of insider trading laws that plausibly reduce the ability of insiders to trade in their own shares, firms appear to respond by increasing the use of equity incentives in the compensation contract. Initial enforcement of insider trading laws is also associated with higher subsequent levels of compensation, though again this might just reflect the higher required risk premium associated with the greater use of equity incentives.

\subsection{Insider ownership and the association between ITR and compensation}

To provide further evidence, we analyze the link between insider ownership and the association between insider trading restrictions and compensation. As noted in Kyle (1985), insider trading is a wealth transfer from uninformed traders to informed traders (insiders). Therefore, insider trading profits will be a decreasing function of the relative number of insiders. Consistent with this prediction, Fidrmuc et al. (2006) find that higher levels of inside ownership are associated with lower insider trading profits. If insider trading profits represent a substitute form of compensation, we expect that restrictions on insider trading will have a smaller impact on compensation arrangements in firms with higher inside ownership since insider trading profits are lower in these firms. Moreover, because the incentives of executives with high inside 
ownership are already well-aligned with those of shareholders, using insider trading as a form of incentive compensation [e.g., Carlton and Fischel (1983) and Manne (1966)] will be less important.

A similar set of predictions can be generated under the view that more stringent insider trading laws allow firms to optimally use greater equity incentives. Again, because the incentives of executives with high inside ownership are already well-aligned with those of shareholders, insider trading restrictions should have less impact on these firms, thereby attenuating the positive association between insider trading restrictions and equity incentives. By contrast, under the view that our primary results are driven by a correlated omitted variable, we expect the level of insider ownership to have no impact on the association between insider trading restrictions and executive compensation.

To test these predictions, we measure insider ownership for the ADR and US firms as the fractional equity ownership (both direct and indirect) of the top executive as reported in the 20-F filings. ${ }^{26}$ We then include an indicator variable equal to one if insider ownership is greater than its country-year median, and the interaction of this indicator with insider trading restrictions in our compensation regressions. The advantage of the indicator variable is that it allows us to abstract from country-level differences in insider ownership; therefore, any results are entirely due to within-country variation in insider ownership and how it relates to the effect of insider trading restrictions on compensation. ${ }^{27}$ The models are estimated with the full set of control variables from Table 2 as well as industry fixed effects although these coefficient estimates are not reported in the table for conciseness.

\footnotetext{
${ }^{26}$ As before, this necessarily limits the analysis to those ADR firms with U.S. style reporting.

${ }^{27}$ Our results are similar if we repeat the analysis using fractional insider ownership directly.
} 
In the regressions for overall equity incentives in Models (1)-(2) of Table 5, the coefficient on the interaction term is negative and statistically significant, indicating that higher ownership attenuates the positive association between insider trading restrictions and equity incentives. In models (3)-(6), we repeat the analysis, but now use the log of Total Pay as the dependent variable. These models also include the log of equity incentives as an additional independent variable. In these models, we again find that higher insider ownership weakens the association between insider trading restrictions and total pay. Moreover, the results in Models (5)-(6) suggest that, even after controlling for overall equity incentives, insider trading restrictions have a significantly positive association with total pay for firms with low insider ownership (i.e., setting InsOwn equal to zero).

\subsection{Other robustness tests}

We conduct a number of other robustness checks that, for purposes of brevity, are not reported in a separate table. First, we test whether our main findings differ between developed and lesser developed countries (LDCs). Consistent with the view that law enforcement is less effective in LDCs, we find that the association between insider trading restrictions (as measured by ITL) and executive compensation is virtually non-existent in LDCs. ${ }^{28}$ Second, to rule out the possibility that a small set of countries drive the results, we exclude from the analysis those countries with more than 30 firms in the sample (Brazil, China, U.K., and U.S.). Our findings are robust to the exclusion of these firms. Third, because executive compensation might differ in regulated industries, we exclude both utilities (SIC codes 4900 to 4949) and financial firms (SIC codes 6000 to 6999). Again, our results are qualitatively unchanged. Fourth, we limit the

\footnotetext{
${ }^{28}$ We follow Bhattacharya and Daouk (2002) to define developed and less developed countries.
} 
sample to the set of CEOs only and continue to find a significant positive association between Equity Incentives and insider trading restrictions.

Fifth, it is possible that cross-listing binds the sample ADR firms to better quality institutions. Because better institutions are associated with lower insider ownership [see, for example, Himmelberg, Hubbard, and Love (2004)], perhaps the impact of insider trading restrictions is unique to our cross-listed sample. To test this possibility, we start with the list of countries and their first insider trading law enforcement events in Table 1. For each event, we then download data from Datastream and Worldscope covering the period from three years before the initial enforcement year through three years after the enforcement. We extract information about closely-held shares, firm characteristics and SIC industry codes. After eliminating firms with missing data, this leaves us with a panel of 4,374 firm-year observations covering 22 countries. We then follow the approach from Table 4 and test whether the fraction of closely held shares (both raw and adjusted for the country average) increases in the years following initial enforcement of insider trading laws. Following our test in Table 5, we differentiate firms that begin with low or high ownership because the effect of insider trading restrictions should be stronger for firms with lower ownership. Consistent with our earlier findings, our results, reported in Table 6, indicate a significant increase in ownership in the years following initial enforcement for firms with below-median lagged ownership. For firms with above-median ownership, the change in ownership is statistically insignificant following initial enforcement of insider trading laws within that country. 


\section{Do insider trading restrictions reduce the insider trading profits of executives?}

To this point, our results support a causal link that runs from insider trading restrictions to equity incentives. Such a causal link might be due to either a substitution between insider trading profits and direct executive compensation or to the existence of stronger insider trading laws allowing firms to optimally use more incentives. The former assumes that insider trading restrictions are correlated with actual reductions in trading profits for executives, while the latter does not. Thus, one way to distinguish between these two views is to report evidence on the extent to which insider trading restrictions actually reduce insider trading profits. Unfortunately, outside of the U.S. and U.K., we are unaware of any systematic data on insider transactions or the profitability of insider trading.

To provide indirect evidence that our measures of insider trading restrictions are associated with diminished insider profits, we analyze the run-up in stock prices of target firms prior to acquisition announcements in each of our sample countries. Prior studies find that preacquisition announcement price run-ups are attributable to informed trading by insiders. For example, Agrawal and Nasser (2012) report significant increases in net purchases by top executives in the six months prior to takeover announcements. Moreover, Arshadi and Eyssell (1991) document a significantly positive association between net insider purchase volume and abnormal returns for target firms prior to tender offer announcements. Taken together, these findings imply that the size of the run-up prior to acquisition announcements is correlated with the extent of informed insider trading and, hence, insider profits.

Following this logic, therefore, we conduct similar tests in our sample countries by estimating regressions of the abnormal price run-up in the month prior to takeover announcements on our measures of insider trading restrictions, ITR and ITL, and a series of 
control variables. Specifically, we first download from SDC Platinum all completed tender offers announced between 1978 and 2011 that involve target firms in countries for which we have insider trading restriction data. We require the transaction value to be at least $\$ 10$ million and include only transactions in which $100 \%$ of the target firm's ownership is transferred. This process results in a sample of 3,007 takeover events in 31 different countries.

For each target firm and its local stock market index, we obtain daily stock return data from Datastream. We compute daily abnormal stock returns for each firm as the difference between the stock return of the target firm and the return of the local stock market index on the same day. Following prior literature [e.g., Jarrell and Poulsen (1989), Keown and Pinkerton (1981), Meulbroek (1992)], we define pre-takeover announcement price run-up as the ratio of the cumulative abnormal return during the 30 days ending one day prior to the takeover announcement date to the cumulative abnormal return from 30 days prior to announcement through one day following the announcement date. ${ }^{29}$ The average run-up in the sample is 0.51 , but exhibits substantial cross-sectional variation (standard deviation $=0.95$ ).

Columns (1)-(4) of Table 7 report estimates from cross-sectional regressions of the pretakeover announcement price run-up on our insider trading restriction measures and a set of other potential determinants of the run-up, including country characteristics (GDP per capita, stock market capitalization and the revised anti-director index), takeover deal characteristics (transaction value, payment method, hostility and the solicitation status), as well as industry and year fixed-effects. The first two columns report estimates from regressions using the entire sample and the ITR and ITL index, respectively, as a measure of insider trading restrictions. Consistent with insider trading restrictions curtailing actual insider trading, the results indicate a

\footnotetext{
${ }^{29}$ Our results are not sensitive the length of the pre-announcement period. We obtain similar results with six-month, two-month, and one-week pre-announcement windows.
} 
significant negative association between the price run-up and insider trading restrictions. In economic terms, a one unit increase in the ITR index corresponds to a decline in the one month price run-up of about 9 percentage points, which approximately equals $20 \%$ of the average level of the run-up and $10 \%$ of its standard deviation.

To ensure that over-represented countries are not driving the results, we also exclude countries with 100 observations or more (Australia, Canada, U.K., and U.S.) and re-estimate the regression model from column (1). The results, presented in column (3), are highly consistent with the other models. Because the ITR index is measured in 1999, we conjecture that it should be most relevant to the price run-ups in years surrounding 1999. Therefore, in column (4), we restrict our sample to the 1996-2002 period and repeat the analysis. Consistent with our conjecture, the ITR index has an unambiguously greater and statistically significant coefficient than in all other columns. Finally, we examine the change in price run-ups around initial enforcement dates of insider trading laws and present the results in column (5). This supplementary analysis allows us to include country fixed-effects in addition to industry and year fixed effects, thereby controlling for country-specific components of price run-ups. Although the power of this test is weakened by the fact that over $90 \%$ of the sample years are after the enforcement dates, the insider trading enforcement dummy nonetheless has a negative coefficient $(\mathrm{t}$-stat $=-1.74)$, suggesting that pre-takeover announcement run-ups are significantly reduced following initial insider trading law enforcement.

Collectively, therefore, the evidence in Table 7 is consistent with the view that our measures of insider trading restrictions capture meaningful reductions in actual insider trading. Nonetheless, it is important to note that even if stronger restrictions on insider trading are associated with lower insider trading profits, it does not necessarily follow that such restrictions 
reduce the trading profits of executives. Although Arshadi and Eyssell (1991) report a reduction in net insider purchases prior to tender offer announcements following the passage of a new insider trading law in the U.S., they also find that the largest effect is on trading by beneficial owners of the target's shares rather than the target's top executives. Our finding of lower runups in countries with stronger insider trading restrictions can thus be viewed as evidence of reduced trading profits for executives only if the trades of executives are correlated with those of other beneficial owners. Consequently, future research with improved data on insider trading is required to conclusively determine whether executive trading profits are indeed lower in countries with stronger insider trading laws.

\section{Summary and Conclusions}

We exploit variation in insider trading restrictions across countries to investigate the link between such restrictions and top executive compensation and incentives. Our results indicate that top executives are significantly more highly paid and hold more equity incentives in countries with stronger insider trading restrictions. These findings are robust to the inclusion of possible country-level and firm-level omitted variables, to panel data specifications, to alternative definitions of insider trading restrictions/enforcement, and to alternative sampling criteria. We also find significant increases in top executive pay and the use of equity-based incentives in the period immediately following the initial enforcement of insider trading laws.

Our findings thus identify insider trading laws as an important (though certainly not the only) channel through which cross-country variation in pay practices can be explained. Although prior studies [e.g., Fernandes et al. (2012); Conyon and Schwalbach (1997)] hint at country-level institutional determinants of compensation structure, identification of the precise 
institutional channels for cross-country variation in pay practices has been elusive. We find that variation in restrictions on insider trading across countries explains a significant amount of the cross-country variation in both the level of explicit pay and the use of equity incentives.

These findings are consistent with two (not mutually exclusive) explanations. First, it is possible that insider trading is an implicit form of compensation and incentives. Thus, when insider trading is restricted, equilibrium in the labor market forces firms to increase total pay and equity incentives. Second, it is possible that stronger insider trading laws allow firms to optimally use greater equity incentives, which in turn, causes total pay to be higher due to managerial risk aversion. Although we provide some indirect evidence that is suggestive of the first view, future research that documents whether stronger insider trading laws are associated with lower executive trading profits is required to establish which explanation best fits the data.

Finally, our findings also complement and extend the large literature on law and finance. La Porta, Lopez-de-Silanes, Shleifer, and Vishny (1998) conclude that laws related to investor protection and their enforcement have an important influence on the distribution of ownership structures across countries. Our findings highlight another important influence of law on finance; namely that laws restricting insider trading affect both the equilibrium level and the use of equity incentives in top executive compensation. One caveat, however, is that our results do not address the efficiency of such laws, nor do we attempt to explain why some countries impose more stringent restrictions on insider trading than do others. These issues also await further study. 


\section{References}

Aboody, David, and Baruch Lev, 2000, Information Asymmetry, R\&D and Insider Gains, Journal of Finance 55, 2747-2766.

Abowd, John M., and Michael L. Bognanno, 1995, International Differences in Executive and Managerial Compensation, in R. Freeman, and L. Katz, ed., Differences and Changes in Wage Structures, Chicago: The University of Chicago Press, 67-103.

Abowd, John M., and David S. Kaplan, 1999, Executive Compensation: Six Questions That Need Answering, Journal of Economic Perspectives 13, 145-168.

Agrawal, Anup, and Tareque Nasser, 2012, Insider trading in takeover targets, Journal of Corporate Finance 18, 598-625.

Arshadi, Nasser, and Thomas H. Eyssell, 1991, Regulatory deterrence and registered insider trading: The case of tender offers, Financial Management 20, 30-39.

Bagnoli, Mark, and Naveen Khanna, 1992, Insider Trading in Financial Signaling Models, Journal of Finance 47(5), 1905-1934.

Baiman, Stanley, and Robert E. Verrecchia, 1995, Earnings and price-based compensation contracts in the presence of discretionary trading and incomplete contracting, Journal of Accounting and Economics 20, 93-121.

Baiman, Stanley, and Robert E. Verrecchia, 1996, The relation among capital markets, financial disclosure, production efficiency, and insider trading, Journal of Accounting Research $34,1-22$.

Baker, George P., Michael C. Jensen, and Kevin J. Murphy, 1988, Compensation and Incentives: Practice vs. Theory, Journal of Finance 43 (3), Papers and Proceedings of the FortySeventh Annual Meeting of the American Finance Association, July 1988, 593-616.

Bekaert, Geert, Harvey, Campbell R., and Lundblad, Christian T., 2001, Emerging Equity Markets And Economic Development, Journal of Development Economics 66(2), 465504.

Beny, Laura Nyantung, 2004, A comparative empirical investigation of agency and market theories of insider trading, working paper, University of Michigan.

Beny, Laura Nyantung, 2006, Do Investors Value Insider Trading Laws? International Evidence, working paper, University of Michigan.

Bhattacharya, Utpal, and Hazem Daouk, 2002, The world price of insider trading, Journal of Finance 57 (1), 75-108. 
Bizjak, John M., Michael L. Lemmon, and Lalitha Naveen, 2008, Does the Use of Peer Groups Contribute to Higher Pay and Less Efficient Compensation, Journal of Financial Economics 90(2), 152-168.

Bryan, Stephen H., Robert C. Nash, and Ajay Patel, 2006, The Structure of Executive Compensation: International Evidence from 1996-2004, http://ssrn.com/abstract=891207.

Bushman, Robert M., Joseph D. Piotroski, and Abbie Smith, 2005, Insider trading restrictions and analysts' incentives to follow firms, Journal of Finance 60(1), 35-66.

Carlton, Dennis W., and Daniel R. Fischel, 1983, The regulation of insider trading, Stanford Law Review 35, 857-895.

Chhaochharia, Vidhi, and Yaniv Grinstein, 2009, CEO compensation and board structure, Journal of Finance 64(1), 231-261.

Conyon, Martin J., John Core, and Wayne Guay, 2011, Are U.S. CEOs paid more than U.K. CEOs? Inferences from risk-adjusted pay, Review of Financial Studies 24(2), 402-438.

Conyon, Martin J., and Joachim Schwalbach, 1997, European Differences in Executive Pay and Corporate Governance, working paper, Warwick Business School.

Damodaran, Aswath, and Crocker H. Liu, 1993, Insider trading as a signal of private information, Review of Financial Studies 6, 79-119.

Djankov, Simeon, Rafael La Porta, Florencio Lopez-de-Silanes, and Andrei Shleifer, 2008, The Law and Economics of Self-Dealing, Journal of Financial Economics 88, 430-465.

Du, Julan, and Shang-Jin Wei, 2004, Does insider trading raise market volatility, Economic Journal 114, 916-942.

Fama, Eugene F., 1980, Agency problems and the theory of the firm, Journal of Political Economy 88(2), 288-307.

Fernandes, Nuno, Miguel A. Ferreira, Pedro Matos, and Kevin J. Murphy, 2012, Are U.S. executives paid more? New international evidence, Review of Financial Studies, forthcoming.

Fidrmuc, Jana P., Marc Goergen, and Luc Renneboog, 2006, Insider trading, news releases, and ownership concentration, Journal of Finance 61(6), 2931-2973.

Himmelberg, Charles P., Glenn Hubbard, and Inessa Love, 2004, Investor protection, ownership, and the cost of capital, World Bank Policy Research Working Paper No. 2834 . 
Jarrell, Gregg, A., and Annette B. Poulsen, 1989, Stock trading before the announcement of tender offers: Insider trading or market anticipation?, Journal of Law, Economics, and Organization 5, 225-248.

Keown, Arthur, J., and John M. Pinkerton, 1981, Merger announcements and insider trading activity: An empirical investigation, Journal of Finance 36, 855-869.

Khanna, Naveen, Steve L. Slezak, and Michael Bradley, 1994, Insider trading, outside search, and resource allocation: Why firms and society may disagree on insider trading restrictions, Review of Financial Studies 7(3), 575-608.

Kyle, Albert, 1985, Continuous auctions and insider trading, Econometrica 53, 1315-1335.

La Porta, Rafael, Florencio Lopez-de-Silanes, Andrei Shleifer, and Robert W. Vishny, 1998, Law and finance, Journal of Political Economy 106(6), 1113-1155.

Levmore, Saul, 1982, Securities and secrets: Insider trading and the law of contracts, Virginia Law Review 68 (1), 117-160.

Manne, Henry G., 1966, Insider Trading and the Stock Market, New York: Free Press.

Meulbroek, Lisa, 1992, An empirical analysis of illegal insider trading, Journal of Finance 47(5), 1661-1698.

Murphy, Kevin J., 1999, Executive compensation, unpublished manuscript, University of Southern California.

Murphy, Kevin J., 2012, Executive Compensation: Where We are, and How We Got There, in G. Constantinides, M. Harris, and R. Stulz eds., Handbook of the Economics of Finance. Elsevier Science North Holland, Forthcoming.

Ortiz-Molina, Hernan, 2007, Executive Compensation and Capital Structure: The Effects of Convertible Debt and Straight Debt on CEO Pay, Journal of Accounting \& Economics 43(1), 69-93.

Roulstone, Darren T., 2003, The relation between insider-trading restrictions and executive compensation, Journal of Accounting Research 41(3), 525-551.

Schotland, Roy A., 1967, Unsafe at any price: A reply to Manne, Insider Trading and the Stock Market, Virginia Law Review 53, 1425-1478.

Seyhun, Nejat H., 1986, Insiders' Profits, Costs of Trading, and Market Efficiency, Journal of Financial Economics 16, 189-212.

Yermack, David, 1995, Do corporations award CEO stock options effectively?, Journal of Financial Economics 39, 237-269. 
World Economic Forum and Harvard University, 1996, 1998, 1999, Global Competitiveness Report, Geneva: World Economic Forum.

Towers Perrin, 1994, 1995, 1996, 1997, 1998, 1999, 2000, 2001-2002, Worldwide Total Remuneration. 


\section{Figure 1: Insider Trading Restriction index and Executive Compensation, 2006}

Scatter plots of country-level executive compensation variables against the Insider Trading Restriction (ITR) index are shown for the year of 2006. The country-level compensation variables are constructed from the equal-weighted averages of all firms for each country. Figure 1A corresponds to total pay in logarithms, Figure 1B corresponds to equity incentives in logarithm, and Figure 1C corresponds to the equity pay ratio.

A. Ln(Total Pay)

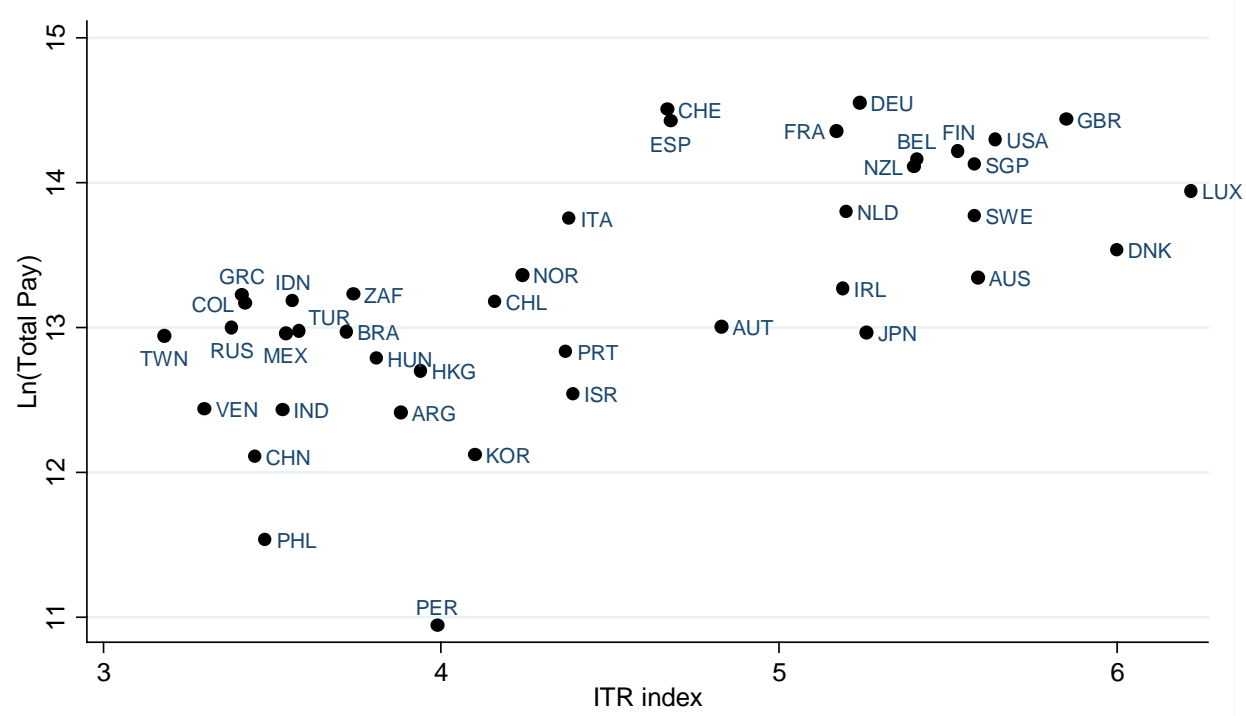

B. Ln(Equity Incentives)

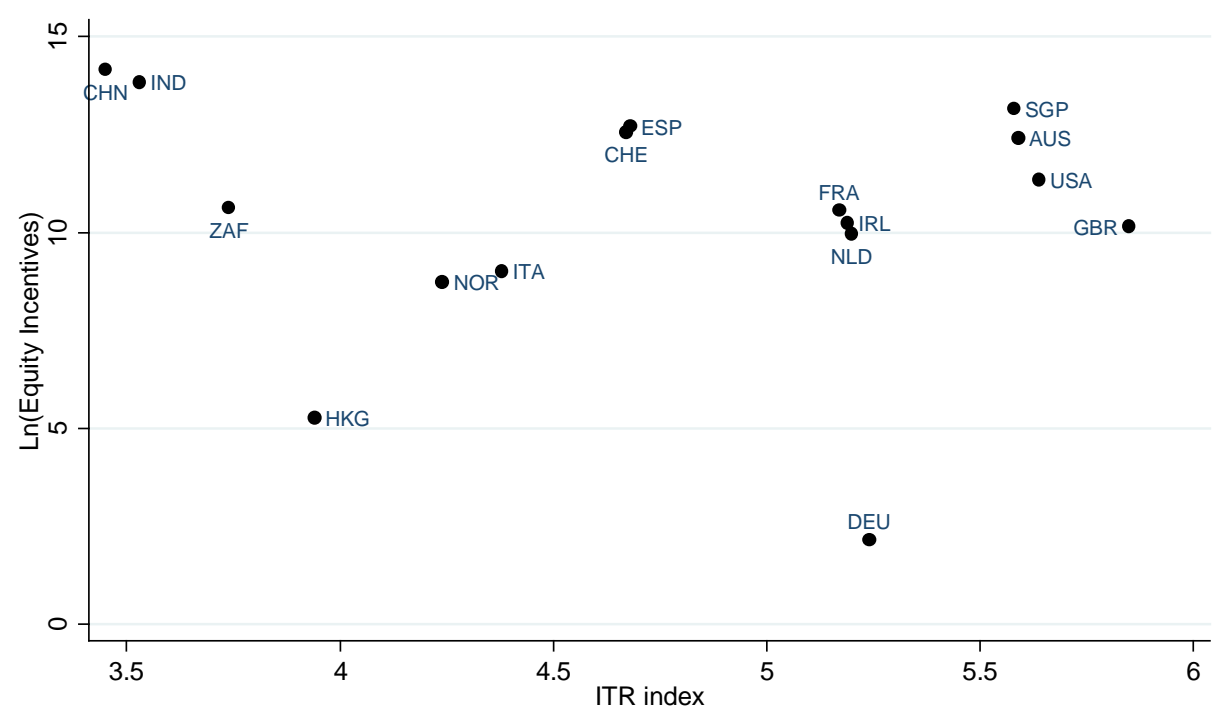


C. Equity Pay Ratio

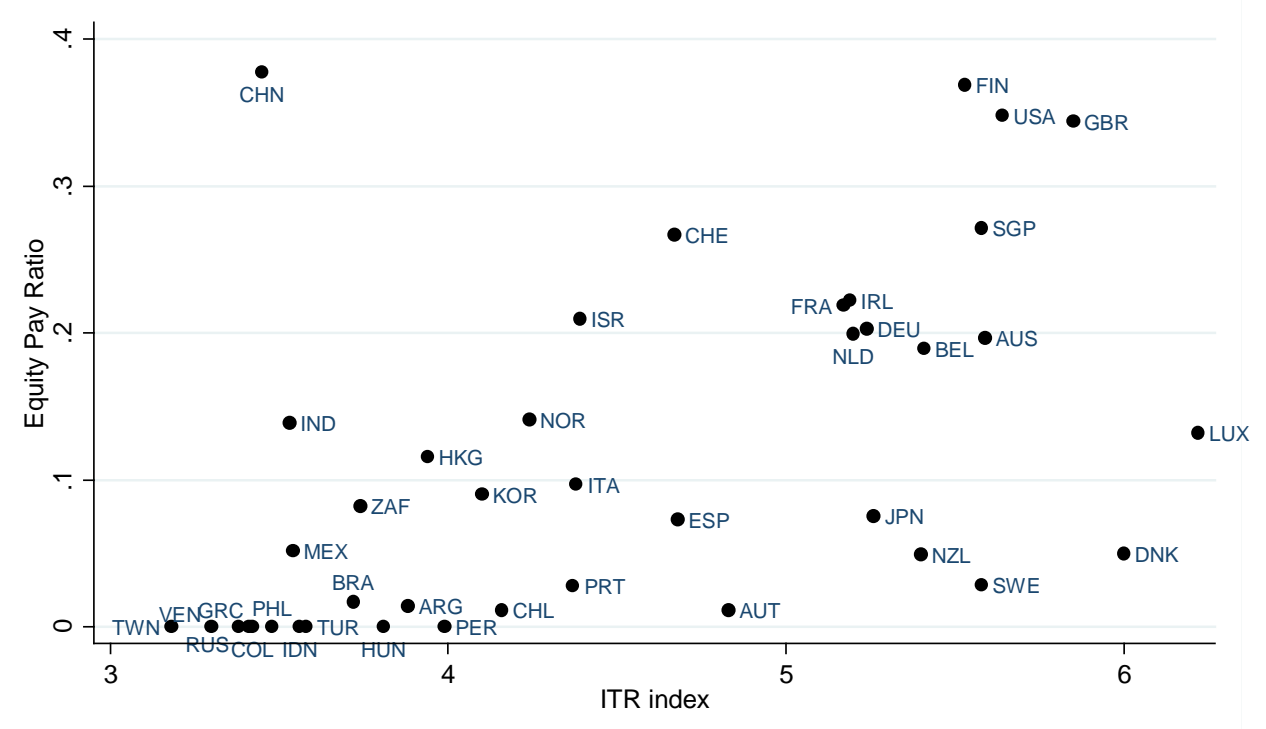


Table 1

Summary Statistics

Panel A reports the sample distribution and the insider trading variables by country. A firm is regarded as following U.S. style reporting if it reports some compensation data at the executive level. Panel B presents variable summary statistics, separately for firms in lower and higher than median ITR countries. Variable definitions are in Appendix A.

Panel A: Sample description by country

\begin{tabular}{|c|c|c|c|c|c|c|c|}
\hline Country & $\begin{array}{c}\text { World Bank } \\
\text { Code }\end{array}$ & \# firms & $\begin{array}{l}\text { \# firms with U.S. } \\
\text { style reporting }\end{array}$ & $\begin{array}{l}\text { ITR } \\
\text { index }\end{array}$ & $\begin{array}{c}\text { ITL } \\
\text { index }\end{array}$ & $\begin{array}{c}\text { IT laws } \\
\text { existence }\end{array}$ & $\begin{array}{c}\text { IT laws } \\
\text { enforcemen }\end{array}$ \\
\hline Argentina & ARG & 14 & 0 & 3.88 & 2 & 1991 & 1995 \\
\hline Australia & AUS & 18 & 18 & 5.59 & 3 & 1991 & 1996 \\
\hline Austria & AUT & 1 & 0 & 4.83 & 2 & 1993 & Never \\
\hline Belgium & BEL & 1 & 1 & 5.41 & 3 & 1990 & 1994 \\
\hline Brazil & BRA & 32 & 0 & 3.72 & 2 & 1976 & 1978 \\
\hline Chile & CHL & 15 & 2 & 4.16 & - & 1981 & 1996 \\
\hline China & CHN & 63 & 10 & 3.45 & - & 1993 & Never \\
\hline Colombia & COL & 1 & 0 & 3.42 & - & 1990 & Never \\
\hline Denmark & DNK & 4 & 2 & 6 & 3 & 1991 & 1996 \\
\hline Finland & FIN & 3 & 3 & 5.53 & 3 & 1989 & 1993 \\
\hline France & FRA & 25 & 24 & 5.17 & 3 & 1967 & 1975 \\
\hline Germany & DEU & 20 & 20 & 5.24 & 3 & 1994 & 1995 \\
\hline Greece & GRC & 4 & 0 & 3.41 & 2 & 1988 & 1996 \\
\hline Hong Kong SAR & HKG & 17 & 6 & 3.94 & 2 & 1991 & 1994 \\
\hline Hungary & HUN & 1 & 0 & 3.81 & - & 1994 & 1995 \\
\hline India & IND & 14 & 13 & 3.53 & 2 & 1992 & 1998 \\
\hline Indonesia & IDN & 2 & 0 & 3.56 & 2 & 1991 & 1996 \\
\hline Ireland & IRL & 10 & 7 & 5.19 & 3 & 1990 & Never \\
\hline Israel & ISR & 8 & 1 & 4.39 & 2 & 1981 & 1989 \\
\hline Italy & ITA & 11 & 7 & 4.38 & 3 & 1991 & 1996 \\
\hline Japan & JPN & 26 & 0 & 5.26 & 2 & 1988 & 1990 \\
\hline Luxembourg & LUX & 6 & 2 & 6.22 & 3 & 1991 & Never \\
\hline Mexico & MEX & 21 & 0 & 3.54 & 1 & 1975 & Never \\
\hline Netherlands & NLD & 19 & 18 & 5.2 & 3 & 1989 & 1994 \\
\hline New Zealand & NZL & 2 & 1 & 5.4 & 2 & 1988 & Never \\
\hline Norway & NOR & 6 & 5 & 4.24 & 1 & 1985 & 1990 \\
\hline Peru & PER & 2 & 0 & 3.99 & - & 1991 & 1994 \\
\hline Philippines & PHL & 2 & 0 & 3.48 & 2 & 1982 & Never \\
\hline Portugal & PRT & 2 & 1 & 4.37 & 3 & 1986 & Never \\
\hline Russia & RUS & 5 & 0 & 3.38 & - & 1996 & Never \\
\hline Singapore & SGP & 2 & 2 & 5.58 & 3 & 1973 & 1978 \\
\hline South Africa & ZAF & 8 & 7 & 3.74 & 2 & 1989 & Never \\
\hline South Korea & KOR & 15 & 0 & 4.1 & 3 & 1976 & 1988 \\
\hline Spain & ESP & 8 & 3 & 4.68 & 2 & 1994 & 1998 \\
\hline Sweden & SWE & 8 & 6 & 5.58 & 3 & 1971 & 1990 \\
\hline Switzerland & CHE & 11 & 7 & 4.67 & 3 & 1988 & 1995 \\
\hline Taiwan & TWN & 8 & 2 & 3.18 & 3 & 1988 & 1989 \\
\hline Turkey & TUR & 1 & 0 & 3.58 & - & 1981 & 1996 \\
\hline United Kingdom & GBR & 51 & 49 & 5.85 & 3 & 1980 & 1981 \\
\hline United States & USA & 1,852 & 1,852 & 5.64 & 3 & 1934 & 1961 \\
\hline Venezuela & VEN & 1 & 0 & 3.3 & - & 1998 & Never \\
\hline Total & & 2,320 & 2,069 & & & & \\
\hline Average & & & & 4.48 & 2.5 & 1986 & 1991 \\
\hline Standard deviation & & & & 0.91 & 0.6 & 10.91 & 8.42 \\
\hline $\begin{array}{l}\text { Correlation with ITR } \\
\text { (P-value) }\end{array}$ & & & & 1 & $\begin{array}{c}0.583 \\
(0.001)\end{array}$ & $\begin{array}{l}-0.254 \\
(0.110)\end{array}$ & $\begin{array}{l}-0.327 \\
(0.037) \\
\end{array}$ \\
\hline
\end{tabular}


Panel B. Variable Summary Statistics

\begin{tabular}{|c|c|c|c|c|c|c|c|c|c|c|}
\hline Variable & \# obs & Mean & Median & Stdev & \# obs & Mean & Median & Stdev & $\begin{array}{l}\text { Diff. in } \\
\text { Means }\end{array}$ & $p$-value \\
\hline & \multicolumn{4}{|c|}{ 1: $I T R<=4.37$} & \multicolumn{4}{|c|}{ 2: ITR $>4.37$} & \multicolumn{2}{|c|}{2 minus 1} \\
\hline \multicolumn{11}{|l|}{ Executive Compensation Variables: } \\
\hline \multicolumn{11}{|l|}{ Firm-level variables: } \\
\hline Ln(Total Pay) & 233 & 12.6 & 12.7 & 1.3 & 2,083 & 14.3 & 14.2 & 0.9 & 1.7 & 0.00 \\
\hline Indicator that total pay includes directors & 234 & 0.59 & 1.00 & 0.49 & 2,086 & 0.03 & 0.00 & 0.18 & -0.55 & 0.00 \\
\hline Equity Pay Ratio & 234 & 0.14 & 0.00 & 0.28 & 2,086 & 0.33 & 0.35 & 0.22 & 0.19 & 0.00 \\
\hline Ln(Equity Incentives) & 34 & 10.4 & 11.4 & 5.3 & 1,631 & 10.6 & 10.8 & 1.9 & 0.2 & 0.84 \\
\hline \multicolumn{11}{|l|}{ Control variables: } \\
\hline \multicolumn{11}{|l|}{ Firm control variables: } \\
\hline Ln(Asset) & 230 & 7.78 & 7.81 & 1.91 & 2,083 & 7.82 & 7.65 & 1.94 & 0.04 & 0.76 \\
\hline $\mathrm{M} / \mathrm{B}$ & 230 & 1.87 & 1.26 & 1.91 & 1,867 & 1.97 & 1.59 & 1.28 & 0.10 & 0.44 \\
\hline $\mathrm{D} / \mathrm{A}$ & 230 & 0.20 & 0.20 & 0.17 & 1,883 & 0.22 & 0.19 & 0.21 & 0.02 & 0.19 \\
\hline ROA & 206 & 0.14 & 0.12 & 0.09 & 1,710 & 0.12 & 0.12 & 0.15 & -0.02 & 0.00 \\
\hline Stock return & 149 & 0.15 & 0.18 & 0.33 & 1,692 & 0.17 & 0.16 & 0.27 & 0.02 & 0.40 \\
\hline Board size & 234 & 10.00 & 9.00 & 3.76 & 1,555 & 9.75 & 9.00 & 2.85 & -0.25 & 0.34 \\
\hline Board independence & 225 & 0.56 & 0.57 & 0.23 & 1,548 & 0.70 & 0.73 & 0.16 & 0.14 & 0.00 \\
\hline R\&D-to-asset & 230 & 0.009 & 0.000 & 0.024 & 2,083 & 0.027 & 0.000 & 0.065 & 0.018 & 0.00 \\
\hline Insider ownership & 162 & 22.86 & 15.97 & 24.98 & 1,995 & 3.26 & 0.07 & 9.43 & -19.61 & 0.00 \\
\hline \multicolumn{11}{|l|}{ Country control variables: } \\
\hline Ln(GDP per capita) & 234 & 9.3 & 9.1 & 0.6 & 2,086 & 10.6 & 10.6 & 0.1 & 1.3 & 0.00 \\
\hline Stock Market Cap/GDP & 234 & 1.10 & 0.90 & 1.11 & 2,086 & 1.46 & 1.48 & 0.20 & 0.36 & 0.00 \\
\hline Anti-director index & 234 & 3.2 & 3.5 & 1.6 & 2,086 & 3.1 & 3.0 & 0.4 & -0.1 & 0.41 \\
\hline
\end{tabular}




\section{Table 2}

\section{Regression Analysis of the Relation between Insider Trading Restriction and Executive Compensation}

This table presents results from Tobit regressions of Ln(Equity Incentives), OLS regressions of Ln(Total Pay) and Tobit regressions of Equity Pay Ratio on insider trading restrictions measures and control variables. The regressions in columns 3, 4, 7 and 8 are conducted at the firm level for the full sample of ADR firms with U.S. firms. Columns 1, 2, 5, 6, 9, 10 present regression results at the executive level for the subsample of firms with U.S. style reporting. All variable definitions can be found in Appendix A. Industry fixed effects are at the 2-digit SIC level. T-statistics based on standard errors clustered by country and robust to heteroskedasticity are reported in the parentheses below the estimated coefficients. *,** and *** indicate statistical significance at the $10 \%, 5 \%$ and $1 \%$ levels, respectively. 


\begin{tabular}{|c|c|c|c|c|c|c|c|c|c|c|}
\hline \multirow{4}{*}{$\begin{array}{c}\text { Dependent Variable: } \\
\text { Sample }\end{array}$} & \multicolumn{6}{|c|}{ Ln(Equity Incentives) } & \multirow{2}{*}{\multicolumn{4}{|c|}{ Equity Pay Ratio }} \\
\hline & \multirow{2}{*}{\multicolumn{2}{|c|}{$\begin{array}{l}\text { Executive level, US style } \\
\text { reporting }\end{array}$}} & \multicolumn{4}{|c|}{ Ln(Total Pay) } & & & & \\
\hline & & & Firm & level & $\begin{array}{r}\text { Executive } \\
\text { style re }\end{array}$ & $\begin{array}{l}\text { level, US } \\
\text { porting }\end{array}$ & \multicolumn{2}{|c|}{ Firm level } & \multicolumn{2}{|c|}{$\begin{array}{l}\text { Executive level, US style } \\
\text { reporting }\end{array}$} \\
\hline & $(1)$ & $(2)$ & $(3)$ & $(4)$ & (5) & $(6)$ & $(7)$ & $(8)$ & $(9)$ & $(10)$ \\
\hline \multicolumn{11}{|c|}{ Insider Trading Restrictions Measure: } \\
\hline ITR index & $\begin{array}{l}2.203^{*} \\
(1.85)\end{array}$ & & $\begin{array}{c}0.385^{* * *} \\
(4.00)\end{array}$ & & $\begin{array}{l}0.208 \\
(0.77)\end{array}$ & & $\begin{array}{l}0.218^{* * *} \\
\quad(5.91)\end{array}$ & & $\begin{array}{c}0.259 * * * \\
\quad(3.27)\end{array}$ & \\
\hline ITL index & & $\begin{array}{l}1.208^{*} \\
(1.78)\end{array}$ & & $\begin{array}{l}0.303^{*} \\
(1.89)\end{array}$ & & $\begin{array}{l}0.353 \\
(0.91)\end{array}$ & & $\begin{array}{c}0.164^{* * *} \\
\quad(3.38)\end{array}$ & & $\begin{array}{c}0.322 * * * \\
(2.82)\end{array}$ \\
\hline \multicolumn{11}{|l|}{ Other incentives: } \\
\hline Ln(Equity incentives) & & & & & $\begin{array}{c}0.069 * * * \\
(6.65)\end{array}$ & $\begin{array}{l}0.070 * * * \\
(6.48)\end{array}$ & & & $\begin{array}{l}-0.002 \\
(-0.94)\end{array}$ & $\begin{array}{l}-0.001 \\
(-0.34)\end{array}$ \\
\hline \multicolumn{11}{|l|}{ Firm Controls: } \\
\hline Ln(Asset) & $\begin{array}{c}0.567 * * * \\
(4.80)\end{array}$ & $\begin{array}{c}0.570 * * * \\
(4.92)\end{array}$ & $\begin{array}{c}0.339 * * * \\
(4.22)\end{array}$ & $\begin{array}{c}0.362^{* * *} \\
(5.25)\end{array}$ & $\begin{array}{c}0.404 * * * \\
(14.79)\end{array}$ & $\begin{array}{c}0.403^{* * *} \\
(14.51)\end{array}$ & $\begin{array}{l}0.047 * * * \\
(5.25)\end{array}$ & $\begin{array}{l}0.048 * * * \\
(5.54)\end{array}$ & $\begin{array}{l}0.068^{* * *} \\
\quad(6.28)\end{array}$ & $\begin{array}{l}0.067 * * * \\
(5.87)\end{array}$ \\
\hline $\mathrm{M} / \mathrm{B}$ & $\begin{array}{l}0.326^{* * *} \\
(2.92)\end{array}$ & $\begin{array}{c}0.339 * * * \\
(3.13)\end{array}$ & $\begin{array}{l}0.071^{* *} \\
(2.03)\end{array}$ & $\begin{array}{l}0.083^{*} \\
(1.77)\end{array}$ & $\begin{array}{l}-0.081 \\
(-0.64)\end{array}$ & $\begin{array}{l}-0.082 \\
(-0.65)\end{array}$ & $\begin{array}{c}0.034^{* * *} \\
(3.44)\end{array}$ & $\begin{array}{c}0.031^{* * *} \\
(2.77)\end{array}$ & $\begin{array}{c}0.045^{* * *} \\
(8.09)\end{array}$ & $\begin{array}{c}0.044^{* * *} \\
(8.77)\end{array}$ \\
\hline $\mathrm{D} / \mathrm{A}$ & $\begin{array}{c}-0.750 * * * \\
(-3.25)\end{array}$ & $\begin{array}{c}-0.758 * * * \\
(-3.36)\end{array}$ & $\begin{array}{l}0.175 \\
(1.24)\end{array}$ & $\begin{array}{l}0.156 \\
(1.13)\end{array}$ & $\begin{array}{c}-0.226^{* *} \\
(-2.54)\end{array}$ & $\begin{array}{c}-0.224^{* *} \\
(-2.49)\end{array}$ & $\begin{array}{c}0.067^{*} \\
(1.74)\end{array}$ & $\begin{array}{l}0.043 \\
(1.53)\end{array}$ & $\begin{array}{l}-0.020 \\
(-1.04)\end{array}$ & $\begin{array}{l}-0.017 \\
(-0.76)\end{array}$ \\
\hline ROA & $\begin{array}{l}0.917 \\
(1.07)\end{array}$ & $\begin{array}{l}0.886 \\
(1.06)\end{array}$ & $\begin{array}{l}-0.324 \\
(-1.17)\end{array}$ & $\begin{array}{l}-0.426 \\
(-1.51)\end{array}$ & $\begin{array}{c}0.748^{*} \\
(1.77)\end{array}$ & $\begin{array}{l}0.772 * \\
(1.80)\end{array}$ & $\begin{array}{l}-0.121 \\
(-1.37)\end{array}$ & $\begin{array}{l}-0.096 \\
(-1.25)\end{array}$ & $\begin{array}{c}-0.140^{* *} \\
(-2.44)\end{array}$ & $\begin{array}{c}-0.128 * * \\
(-2.34)\end{array}$ \\
\hline Stock return & $\begin{array}{c}0.325 * * \\
(2.23)\end{array}$ & $\begin{array}{c}0.327 * * \\
(2.24)\end{array}$ & $\begin{array}{l}-0.119 \\
(-0.75)\end{array}$ & $\begin{array}{l}-0.125 \\
(-0.64)\end{array}$ & $\begin{array}{c}0.208^{* * *} \\
(4.49)\end{array}$ & $\begin{array}{c}0.216^{* * * *} \\
(5.20)\end{array}$ & $\begin{array}{c}-0.050^{*} \\
(-1.67)\end{array}$ & $\begin{array}{l}-0.022 \\
(-0.69)\end{array}$ & $\begin{array}{c}-0.078 * * * \\
(-3.62)\end{array}$ & $\begin{array}{c}-0.072 * * * \\
(-4.03)\end{array}$ \\
\hline Board size & $\begin{array}{l}0.024 \\
(1.49)\end{array}$ & $\begin{array}{l}0.017 \\
(1.00)\end{array}$ & $\begin{array}{l}0.006 \\
(0.44)\end{array}$ & $\begin{array}{l}0.004 \\
(0.30)\end{array}$ & $\begin{array}{l}-0.011 \\
(-0.43)\end{array}$ & $\begin{array}{l}-0.012 \\
(-0.43)\end{array}$ & $\begin{array}{l}-0.004 \\
(-1.30)\end{array}$ & $\begin{array}{l}-0.005 \\
(-1.56)\end{array}$ & $\begin{array}{c}0.008^{* * *} \\
(3.31)\end{array}$ & $\begin{array}{c}0.008^{* * *} \\
(3.07)\end{array}$ \\
\hline Board independence & $\begin{array}{l}-0.317 \\
(-0.65)\end{array}$ & $\begin{array}{l}-0.247 \\
(-0.40)\end{array}$ & $\begin{array}{c}0.566^{* *} \\
(2.12)\end{array}$ & $\begin{array}{l}0.294 \\
(1.38)\end{array}$ & $\begin{array}{c}0.488 * * \\
(2.38)\end{array}$ & $\begin{array}{c}0.489 * * \\
(2.28)\end{array}$ & $\begin{array}{l}0.117^{*} \\
(1.95)\end{array}$ & $\begin{array}{c}0.150 * * * \\
(3.80)\end{array}$ & $\begin{array}{c}0.247^{* * * *} \\
(8.03)\end{array}$ & $\begin{array}{c}0.244^{* * *} \\
(8.36)\end{array}$ \\
\hline R\&D-to-asset & $\begin{array}{c}2.559 * * * \\
(2.82)\end{array}$ & $\begin{array}{c}2.272 * * * \\
(2.72)\end{array}$ & $\begin{array}{c}1.461^{* * *} \\
(2.79)\end{array}$ & $\begin{array}{c}1.456 * * \\
(2.60)\end{array}$ & $\begin{array}{c}1.103 * * \\
(2.55)\end{array}$ & $\begin{array}{c}1.091^{* *} \\
(2.58)\end{array}$ & $\begin{array}{c}0.595^{* * * *} \\
(3.63)\end{array}$ & $\begin{array}{c}0.543 * * * \\
(2.97)\end{array}$ & $\begin{array}{c}0.313^{* *} \\
(2.24)\end{array}$ & $\begin{array}{l}0.298 * \\
(1.94)\end{array}$ \\
\hline \multicolumn{11}{|l|}{ Country Controls: } \\
\hline Ln(GDP per capita) & $\begin{array}{c}-3.626 * * \\
(-2.48)\end{array}$ & $\begin{array}{c}-1.774 * * * \\
(-3.43)\end{array}$ & $\begin{array}{c}0.349 * * \\
(2.07)\end{array}$ & $\begin{array}{c}0.453 * * * \\
(3.14)\end{array}$ & $\begin{array}{c}0.761 * * \\
(2.35)\end{array}$ & $\begin{array}{c}0.815^{* * *} \\
(3.65)\end{array}$ & $\begin{array}{l}-0.056 \\
(-0.96)\end{array}$ & $\begin{array}{c}0.202^{* *} \\
(2.09)\end{array}$ & $\begin{array}{l}0.014 \\
(0.14)\end{array}$ & $\begin{array}{l}0.130 \\
(1.48)\end{array}$ \\
\hline Stock Market Cap/GDP & $\begin{array}{l}0.584 \\
(0.60)\end{array}$ & $\begin{array}{l}0.207 \\
(0.22)\end{array}$ & $\begin{array}{l}0.080 \\
(1.13)\end{array}$ & $\begin{array}{l}0.101 \\
(1.18)\end{array}$ & $\begin{array}{l}0.040 \\
(0.24)\end{array}$ & $\begin{array}{l}0.026 \\
(0.17)\end{array}$ & $\begin{array}{c}0.105^{* * * *} \\
(4.31)\end{array}$ & $\begin{array}{c}0.059 * \\
(1.90)\end{array}$ & $\begin{array}{c}0.192^{* * *} \\
(3.64)\end{array}$ & $\begin{array}{c}0.164^{* * *} \\
(2.64)\end{array}$ \\
\hline
\end{tabular}


Anti-director index

Indicator that total pay

includes directors

\section{Executive Controls:}

CEO indicator

Executive age

Constant

Industry Fixed Effects

Number of country clusters

Number of observations

Adj.Pseudo $\mathrm{R}^{2}$

\section{$-0.015$}

$(-0.19)$

$-0.992 * *$

$(-9.22)$ $-0.960 * * *$$$
(-7.61)
$$

$0.049 \quad 0.073$

(0.64)

(1.20)

$-0.074 * * *$

$(-3.69)$

$-0.008$

$(-0.32)$

$-0.079 * *$

$(-2.51)$

$-0.045$

\section{$1.631 * * * \quad 1.612 * * *$}

(33.96) (26.39)

$0.061^{* * *} \quad 0.061^{* * *}$

$$
\text { (7.01) }
$$

(6.46)

2.046*** 2.059***

(18.02) (16.39)

Yes

$\begin{array}{cc}16 & 15 \\ 1,715 & 1,710\end{array}$

$0.096 \quad 0.093$

$\begin{array}{cccc} & & 0.784 * * * & 0.785^{* * *} \\ & & (24.14) & (24.55) \\ & & 0.004^{* * *} & 0.003^{* * *} \\ & & (3.44) & (3.26) \\ 5.534 * * * & 5.865^{* * *} & 0.717 & 0.025 \\ (3.49) & (3.87) & (0.32) & (0.02)\end{array}$

Yes

1,165

0.586
Yes

1,118

0.572

$\begin{array}{cc}\text { Yes } & \text { Yes } \\ 16 & 15\end{array}$

$1,693 \quad 1,688$

$1,693 \quad 1,688$

$0.577 \quad 0.571$

\begin{tabular}{l}
15 \\
571 \\
\hline
\end{tabular}

$0.229 * * *$

(9.96)
$0.080 * * * \quad 0.078 * * *$

(17.86) (14.99)

$-0.003^{* * *}-0.003^{* * *}$

$(-7.04) \quad(-7.12)$

$0.280 * * * \quad 0.280^{* * *}$

(136.90) (121.97)

\begin{tabular}{cccc}
40 & Yes & Yes & Yes \\
\hline & 33 & 16 & 15
\end{tabular}

$\begin{array}{cccc}40 & 33 & 16 & 15 \\ 1,166 & 1,119 & 1,693 & 1,688\end{array}$

$\begin{array}{llll}1,166 & 1,119 & 1,693 & 1,688\end{array}$

$\begin{array}{llll}0.639 & 0.652 & 0.337 & 0.329\end{array}$




\section{Table 3}

Panel Data Regressions of Incentive Pay on Insider Trading Restriction, 1996-1999

This table presents results from regressions of the survey-based Incentive Pay Measure (IPM) on the Insider Trading Restriction Index and control variables. For the change specification, the dependent variable is the year-on-year change of IPM and the independent variables are the year-on-year changes of their level counterparts. All variable definitions can be found in Appendix A. T-statistics based on standard errors clustered by country and robust to heteroskedasticity are reported in the parentheses below the estimated coefficients. ${ }^{*}, * *$ and $* * *$ indicate statistical significance at the $10 \%, 5 \%$ and $1 \%$ levels, respectively.

\begin{tabular}{|c|c|c|c|c|}
\hline & \multicolumn{2}{|c|}{ Level Specification } & \multicolumn{2}{|c|}{ Change Specification } \\
\hline & (1) & (2) & (3) & (4) \\
\hline \multirow[t]{2}{*}{ ITR index } & $0.474 * * *$ & $0.380 * *$ & $0.229 * *$ & $0.256 * *$ \\
\hline & $(6.38)$ & $(2.19)$ & $(2.67)$ & $(2.16)$ \\
\hline \multirow[t]{2}{*}{ Ln(GDP per capita) } & & -0.915 & & -0.498 \\
\hline & & $(-0.62)$ & & $(-0.42)$ \\
\hline \multirow[t]{2}{*}{ Stock Market Cap/GDP } & & -0.008 & & -0.039 \\
\hline & & $(-0.06)$ & & $(-0.35)$ \\
\hline \multirow[t]{2}{*}{ Constant } & $2.114 * * *$ & 10.370 & $0.423 * * *$ & $0.459 * * *$ \\
\hline & (6.65) & $(0.80)$ & $(10.09)$ & (8.35) \\
\hline Fixed Effects & No & $\begin{array}{c}\text { Country, } \\
\text { Year }\end{array}$ & No & Year \\
\hline Number of country clusters & 59 & 56 & 53 & 50 \\
\hline Number of observations & 161 & 154 & 102 & 98 \\
\hline Adj. $R^{2}$ & 0.324 & 0.794 & 0.049 & 0.016 \\
\hline
\end{tabular}




\section{Table 4}

\section{Relation between Insider Trading Laws and Executive Compensation}

This table presents variable summary statistics (Panel A) and results from regressions of the logarithmic Total Pay and the Equity Pay Ratio on IT Enforce and control variables (Panel B). IT Enforce is an indicator for the year of and years following the initial enforcement of insider trading laws. In columns 1 and 3, all variables are raw variables. In columns 2 and 4, all variables are country-adjusted. A countryadjusted variable is the raw variable adjusted by its country average. Year indicators are included in all models. T-statistics based on standard errors clustered by country and robust to heteroskedasticity are reported in the parentheses below the estimated coefficients. *, ** and *** indicate statistical significance at the $10 \%, 5 \%$ and $1 \%$ levels, respectively.

Panel A. Variable Summary Statistics

\begin{tabular}{lccccccccc}
\hline Variable (Raw) & Mean & Median Stdev & Mean & Median Stdev & $\begin{array}{c}\text { Diff. in } \\
\text { Means }\end{array}$ & P-value \\
\hline & \multicolumn{7}{c}{ IT Enforce $=0(N=43)$} & IT Enforce $=1(N=139)$ & \\
Ln(Total Pay) & 12.24 & 12.31 & 0.49 & 12.61 & 12.66 & 0.40 & 0.37 & $<0.001$ \\
Equity Pay Ratio & 0.030 & 0.000 & 0.055 & 0.114 & 0.115 & 0.107 & 0.084 & $<0.001$ \\
Ln(GDP per capita) & 8.81 & 8.61 & 0.77 & 9.79 & 9.96 & 0.62 & 0.98 & $<0.001$ \\
Stock Market Cap/GDP & 0.53 & 0.34 & 0.52 & 1.03 & 0.88 & 0.72 & 0.50 & $<0.001$ \\
\hline
\end{tabular}

Panel B. Regressions

\begin{tabular}{|c|c|c|c|c|}
\hline \multirow[t]{2}{*}{ Dependent } & \multicolumn{2}{|c|}{ Ln(Total Pay) } & \multicolumn{2}{|c|}{ Equity Pay Ratio } \\
\hline & $\begin{array}{l}\text { Raw } \\
(1)\end{array}$ & $\begin{array}{l}\text { Country- } \\
\text { adjusted } \\
(2)\end{array}$ & $\begin{array}{l}\text { Raw } \\
(3)\end{array}$ & $\begin{array}{c}\text { Country- } \\
\text { adjusted } \\
(4)\end{array}$ \\
\hline IT Enforce & $\begin{array}{l}0.058 \\
(0.25)\end{array}$ & $\begin{array}{c}0.136^{* *} \\
(2.38)\end{array}$ & $\begin{array}{c}0.068 * * * \\
(3.74)\end{array}$ & $\begin{array}{c}0.012^{* *} \\
(2.51)\end{array}$ \\
\hline Equity Pay Ratio & $\begin{array}{c}2.403^{* * *} \\
(4.75)\end{array}$ & $\begin{array}{l}0.715^{*} \\
(1.79)\end{array}$ & & \\
\hline Ln(GDP per capita) & $\begin{array}{l}0.169 \\
(1.42)\end{array}$ & $\begin{array}{l}-0.295 \\
(-0.90)\end{array}$ & $\begin{array}{l}-0.006 \\
(-0.31)\end{array}$ & $\begin{array}{c}-0.098 * * \\
(-2.12)\end{array}$ \\
\hline Stock Market Cap/GDP & $\begin{array}{l}-0.045 \\
(-0.67)\end{array}$ & $\begin{array}{l}0.025 \\
(0.28)\end{array}$ & $\begin{array}{l}0.031 \\
(1.60)\end{array}$ & $\begin{array}{l}-0.014 \\
(-0.85)\end{array}$ \\
\hline Constant & $\begin{array}{c}10.786^{* * *} \\
(9.95)\end{array}$ & $\begin{array}{l}-0.109 \\
(-1.57)\end{array}$ & $\begin{array}{l}0.052 \\
(0.29)\end{array}$ & $\begin{array}{c}-0.055^{* * *} \\
(-5.68)\end{array}$ \\
\hline Year Fixed Effects & Yes & Yes & Yes & Yes \\
\hline Number of country clusters & 25 & 25 & 25 & 25 \\
\hline Number of observations & 181 & 181 & 181 & 181 \\
\hline Adj. $R^{2}$ & 0.368 & 0.153 & 0.294 & 0.557 \\
\hline
\end{tabular}




\section{Table 5}

\section{Insider Ownership and the Association between Insider Trading Restriction and Executive Compensation}

This table presents results of Tobit regressions of Ln(Equity Incentives) and OLS regressions of Ln(Total Pay) on insider trading restrictions measures, an indicator that percentage insider ownership is greater than the country-year median (HighInsOwn), their interactions, and the same set of firm and country control variables as in Table 2 (the coefficients of the control variables are omitted for brevity). The regressions in columns 1, 2, 5, 6 present regression results at the executive level for the subsample of firms with U.S. style reporting. Columns 3 and 4 are conducted at the firm level for the full sample of ADR firms with U.S. firms. All variable definitions can be found in Appendix A. 2-digit SIC industry fixed effects are included in all regressions. T-statistics based on robust standard errors clustered by country and robust to heteroskedasticity are reported in the parentheses below the estimated coefficients. $*$, ** and *** indicate statistical significance at the $10 \%, 5 \%$ and $1 \%$ levels, respectively.

\section{Dependent Variable: \\ Ln(Equity Incentives) \\ Executive level, US style reporting}

Firm level

\section{Insider Trading Restrictions Measure:}

HighInsOwn*ITR index $\quad-0.605^{*}$

ITR index

HighInsOwn*ITL index

ITL index

HighInsOwn

\section{Other incentives:}

Ln(Equity incentives)

Executive Controls
Industry Fixed Effects

Number of country clusters

Number of observations

Adj./Pseudo $\mathrm{R}^{2}$
Ln(Total Pay)

Executive level, US style reporting

(5)

(6)
(3)

2.016*
(2)
(4)

$\begin{array}{cc}-0.390 * * * & -0.868 * * * \\ (-4.20) & (-3.80) \\ 0.589 * * * & 0.460 * \\ (5.80) & (1.81)\end{array}$

$-2.372 * * *$

$(-3.03)$

$1.657 * * *$

(3.77)

$4.571^{* *} \quad 8.290 * * *$

(2.56)

(3.50)

$2.185^{* * *}$

(4.24)

$-0.326$

$(-1.69)$

$0.548 * *$

(2.09)

0.995*

(1.71)

4.839***

(3.78)

$-2.206 * * *$

(-8.58)

$0.607^{*}$

(2.12)

$6.569 * * *$

(8.59)

$0.065 * * * \quad 0.064 * * *$

(11.22) (10.30)

Yes Yes

Yes Yes

Yes Yes

Yes Yes

$15 \quad 14$

1,679

1,674

0.113

0.114

Yes

Yes Yes

No No

Yes

Yes

$\begin{array}{cccc}\text { Yes } & \text { Yes } & \text { Yes } & \text { Yes } \\ 38 & 31 & 15 & 14 \\ 1,047 & 1,013 & 1,657 & 1,652 \\ 0.633 & 0.613 & 0.590 & 0.587\end{array}$




\section{Table 6}

\section{Changes in Inside Ownership following Initial Enforcement of Insider Trading Laws}

The dependent variable is the closely-held ownership, defined as closely-held shares as a percentage of the total shares outstanding. 'High Prior Ownership' is a dummy variable taking the value of one if the firm's pre-enforcement closely-held ownership is above the median and zero otherwise. Industry fixed effects are at the 2-digit SIC level. T-statistics based on standard errors clustered by country and robust to heteroskedasticity are reported in parentheses below the estimated coefficients. $*$, $* *$ and $* * *$ indicate statistical significance at the $10 \%, 5 \%$ and $1 \%$ levels, respectively.

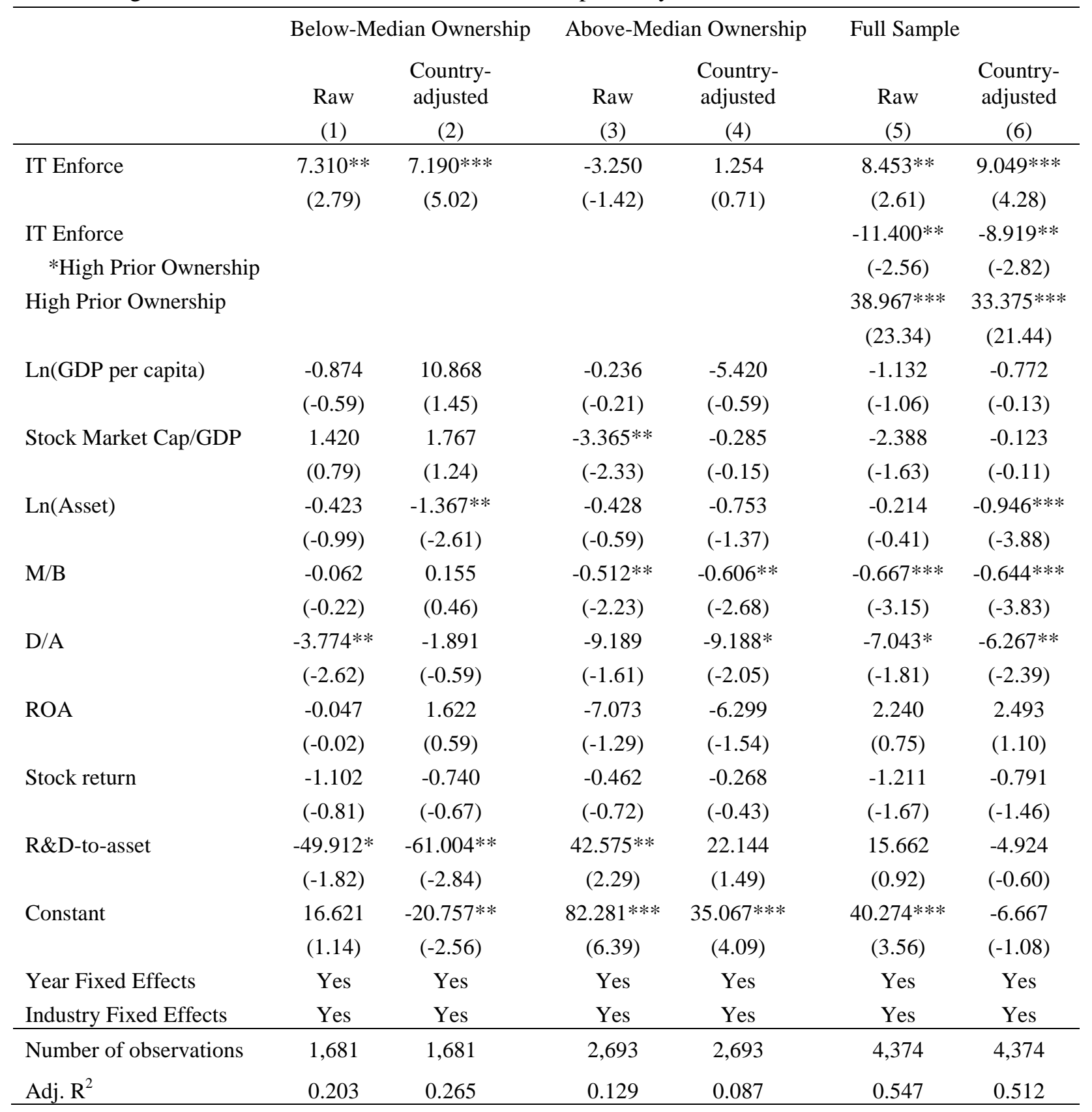




\section{Table 7}

\section{Target Firm Stock Price Run-ups before Takeover Announcements}

The dependent variable is "one month price run-up", defined as the ratio of the cumulative abnormal stock return of the target firm in the 1 month prior to the takeover announcement and the cumulative abnormal stock return from 1 month prior to announcement through 1 day after the announcement. Abnormal stock return is defined as the difference in the stock return of a target firm and the return of its local stock market index during the same day. IT Enforce is an indicator for the year of and years following the initial enforcement of insider trading laws. Column 3 excludes countries with more than 100 observations in the sample. The country control variables in regressions 1-4 come from Djankov et al. (2008) while GDP per capita in regression 5 comes from World Bank and is measured yearly. All other variable definitions can be found in Appendix A. All regressions include year fixed-effects and industry fixed-effects at the 2-digit SIC level except in column 3, which includes industry fixed effects at the 1digit SIC level. T-statistics based on robust standard errors clustered by country and robust to heteroskedasticity are reported in the parentheses below the estimated coefficients. *, ** and *** indicate statistical significance at the $10 \%, 5 \%$ and $1 \%$ levels, respectively.

\begin{tabular}{|c|c|c|c|c|c|}
\hline & $\begin{array}{l}\text { All Country- } \\
\text { years } \\
\text { (1) }\end{array}$ & $\begin{array}{l}\text { All Country- } \\
\text { years } \\
\text { (2) }\end{array}$ & $\begin{array}{c}\text { Excl. Over- } \\
\text { represented, All } \\
\text { Years } \\
\text { (3) }\end{array}$ & $\begin{array}{c}\text { Years } 1996 \\
\text { to } 2002 \\
(4)\end{array}$ & $\begin{array}{l}\text { All Country- } \\
\text { years } \\
\text { (5) }\end{array}$ \\
\hline ITR index & $\begin{array}{c}-0.093 * * \\
(-2.22)\end{array}$ & & $\begin{array}{c}-0.126 * * \\
(-2.21)\end{array}$ & $\begin{array}{c}-0.246^{* * *} \\
(-3.66)\end{array}$ & \\
\hline ITL index & & $\begin{array}{c}-0.102 * * \\
(-2.75)\end{array}$ & & & \\
\hline IT Enforce & & & & & $\begin{array}{c}-0.180^{*} \\
(-1.74)\end{array}$ \\
\hline Ln(GDP per capita) & $\begin{array}{l}0.111 \\
(1.17)\end{array}$ & $\begin{array}{l}-0.007 \\
(-0.06)\end{array}$ & $\begin{array}{l}0.060 \\
(0.49)\end{array}$ & $\begin{array}{c}0.443^{* *} \\
(2.62)\end{array}$ & $\begin{array}{l}0.145 \\
(0.13)\end{array}$ \\
\hline Stock Market Cap/GDP & $\begin{array}{l}-0.035 \\
(-1.35)\end{array}$ & $\begin{array}{l}-0.022 \\
(-0.79)\end{array}$ & $\begin{array}{c}-0.048 * * \\
(-2.35)\end{array}$ & $\begin{array}{l}-0.015 \\
(-0.42)\end{array}$ & \\
\hline Anti-director index & $\begin{array}{c}0.052^{* *} \\
(2.69)\end{array}$ & $\begin{array}{l}0.022 \\
(1.07)\end{array}$ & $\begin{array}{l}0.007 \\
(0.17)\end{array}$ & $\begin{array}{c}0.134 * * * \\
(4.30)\end{array}$ & \\
\hline Ln(Deal value) & $\begin{array}{c}0.018^{* *} \\
(2.07)\end{array}$ & $\begin{array}{l}0.018^{*} \\
(2.01)\end{array}$ & $\begin{array}{l}0.017 \\
(0.69)\end{array}$ & $\begin{array}{l}0.016 \\
(0.90)\end{array}$ & $\begin{array}{c}0.020 * * \\
(2.43)\end{array}$ \\
\hline Stock bid & $\begin{array}{c}0.053 * * * \\
(2.84)\end{array}$ & $\begin{array}{c}0.054 * * * \\
(2.91)\end{array}$ & $\begin{array}{l}-0.021 \\
(-0.22)\end{array}$ & $\begin{array}{l}0.090 \\
(1.54)\end{array}$ & $\begin{array}{c}0.049 * * \\
(2.66)\end{array}$ \\
\hline Hostile & $\begin{array}{c}-0.185^{* * * *} \\
(-5.32)\end{array}$ & $\begin{array}{c}-0.185^{* * * *} \\
(-5.31)\end{array}$ & $\begin{array}{l}0.232 \\
(0.88)\end{array}$ & $\begin{array}{l}-0.085 \\
(-1.03)\end{array}$ & $\begin{array}{c}-0.204^{* * * *} \\
(-6.67)\end{array}$ \\
\hline Unsolicited & $\begin{array}{c}0.103^{* *} \\
(2.20)\end{array}$ & $\begin{array}{c}0.106^{* *} \\
(2.29)\end{array}$ & $\begin{array}{c}-0.381^{*} \\
(-1.85)\end{array}$ & $\begin{array}{l}0.013 \\
(0.15)\end{array}$ & $\begin{array}{c}0.110^{* *} \\
(2.42)\end{array}$ \\
\hline Fixed Effects & $\begin{array}{c}\text { Industry, } \\
\text { Year }\end{array}$ & $\begin{array}{c}\text { Industry, } \\
\text { Year }\end{array}$ & $\begin{array}{l}\text { Industry, } \\
\text { Year }\end{array}$ & $\begin{array}{c}\text { Industry, } \\
\text { Year }\end{array}$ & $\begin{array}{c}\text { Industry, } \\
\text { Country, } \\
\text { Year }\end{array}$ \\
\hline Number of country clusters & 31 & 28 & 27 & 25 & 31 \\
\hline Number of observations & 3,007 & 3,003 & 382 & 1,396 & 3,007 \\
\hline $\mathrm{R}^{2}$ & 0.033 & 0.033 & 0.085 & 0.051 & 0.039 \\
\hline
\end{tabular}




\section{Appendix A: Variable definitions}

\section{Executive compensation variables}

Total Pay = salary + bonus + other annual (including perquisites and severance pay) + other compensation (primarily pension) + restricted stock awards (value at time of award) + option grants (Black-Scholes value at time of grant). Total Pay is in U.S. Dollars. Ln(Total Pay) is the natural logarithm of Total Pay.

Equity Pay Ratio = (restricted stock awards + option grants) $/$ Total Pay

Equity Incentives is the change in the value of executive share ownership as reported when the stock price changes by $1 \%$. The reported share ownership is based on fully diluted shares, i.e., assuming all options outstanding are exercised.

Note: In many analyses in the paper, firm-level pay variables are used. To construct the firm-level pay variables, we follow the algorithm detailed below:

When data is available at the executive level, a firm-level compensation variable is the equally-weighted average of the executive-level variable for the top five highest-paid executives or all executives with available compensation data (if there are fewer than five executives with available data).

When only firm-level aggregate data is available, firm-level compensation variables are derived from the aggregate data. Firm-level Total Pay is the firm aggregate compensation, divided by the number of executives (and directors) included in the aggregate compensation figure. Firm-level Equity Pay Ratio is the ratio of aggregate stock and option awards to total pay.

\section{Insider trading restriction variables}

ITR Index is the Insider Trading Restriction Index obtained from the 1996, 1998 and 1999 Global Competitiveness Report based on the following question: "Insider trading is not common in the domestic market (1=strongly disagree, 7=strongly agree)”.

ITL Index is drawn from Beny $(2004,2006)$ and is the sum of three binary variables summarizing insider trading laws in place in 36 countries as of 1994, namely, Tippee, Tipping, and Criminal. Tippee equals 1 if tippees (i.e., a corporate outsider receiving inside information from an insider) are subject to insider trading regulation and 0 otherwise. Tipping equals 1 if an insider can be held liable for tipping outsiders and 0 otherwise. Criminal is 1 if violation of the insider trading law is a criminal offense and 0 otherwise.

\section{Control variables}

Ln(Asset) is the logarithm of the total book value of assets. Asset is in millions of US Dollars.

$\mathbf{M} / \mathbf{B}$ is the ratio of the market value of assets (market value of equity plus book value of debt) over the book value of assets.

$\mathbf{D} / \mathbf{A}$ is the ratio of the book value of debt (long-term debt plus debt in short-term liabilities) over the book value of assets. 
ROA is the ratio of operating income before depreciation and amortization over the book value of assets, lagged by one year.

Stock return is the annual stock return including dividends, lagged by one year.

Board size is the number of board of directors. Source: 20-F reports.

Board independence is the fraction of independent directors on the board. Both board size and board independence variables are collected from the 20-F filings. Following the Riskmetrics' (formerly IRRC's) definition, an independent director is someone who is not an officer or a former officer, who does not provide (or does not work for an employer that provides) professional services to the company, and who is not a major customer, or family member of a director or executive. Source: 20-F reports.

Insider ownership is the share ownership by executives, including both their direct ownership in the firm and indirect ownership through their close relatives or another company as revealed in the 20-F filing. When used in firm level tests, it is total ownership by all officers and directors.

Indicator that total pay includes directors: A dummy variable that is 0 if firm aggregate pay only includes executive officers (regardless of whether she is on the board), and is 1 if it includes both executive officers and non-executive directors.

CEO is a dummy variable that is 1 if the executive is the Chief Executive Officer.

Age is the age of the executive.

Ln(GDP per capita) is the Logarithmic of per capita Gross Domestic Product (in U.S. dollars). Source: World Development Indicators by the World Bank

Stock Market Cap/GDP is the Average of the ratio of stock market capitalization to gross domestic product. Source: World Development Indicators by the World Bank.

Anti-director Index is the Revised Anti-director Index from Djankov, La Porta, and Lopez-de-Silanes (2008). Available for 72 countries, this index is constructed based on laws and regulations applicable to publicly traded firms in May 2003, and summarizes the protection of minority shareholders in the corporate decision-making process.

\section{Additional variables used in panel datasets}

Incentive Pay Measure (IPM) is the mean score of the responses to the following survey questions in the Global Competitiveness Reports. "Non-wage incentives (such as profit sharing and stock purchase plans) are used effectively to motivate employees (1=strongly disagree, 6=strongly agree)" (1996). “Compensation policies link pay closely with job performance (1=strongly disagree, $7=$ =strongly agree)" (1998 and 1999).

Total Pay is Total Remuneration for CEO in U.S. Dollars, converted to 1982-1984 real terms. Source: Worldwide Total Remuneration reports by Towers Perrin. 
Equity Pay Ratio is the fraction of Long-term Incentives in Total Remuneration. Long-term Incentives capture the annual expected value of stock options, stock grants and other long-term incentive awards. Source: Worldwide Total Remuneration reports by Towers Perrin.

IT Enforce is an indicator for the year of and years following the initial enforcement of insider trading laws. Source: Bhattacharya and Daouk (2002).

\section{Variables used in takeover price run-up tests}

$\mathbf{L n}($ Deal value) is the natural logarithm of the transaction value of the takeover in \$mil.

Stock bid is an indicator that is 1 if the method of payment of the takeover contains stock and 0 otherwise.

Hostile is an indicator that is 1 if the takeover is identified as "Hostile" in SDC.

Unsolicited is an indicator that is 1 if the bid is identified as "Unsolicited" by managers in SDC. 
Appendix B: ITR indexes in 1996-1999

\begin{tabular}{|c|c|c|c|}
\hline Country & $\begin{array}{c}\text { ITR index } \\
96 \\
\end{array}$ & $\begin{array}{c}\text { ITR index } \\
98 \\
\end{array}$ & $\begin{array}{c}\text { ITR index } \\
99 \\
\end{array}$ \\
\hline Argentina & 3.21 & 4.05 & 3.88 \\
\hline Australia & 5.04 & 5.27 & 5.59 \\
\hline Austria & 4.5 & 4.8 & 4.83 \\
\hline Belgium & 4.36 & 5 & 5.41 \\
\hline Bolivia & . & . & 3.86 \\
\hline Brazil & 3.14 & 3.8 & 3.72 \\
\hline Bulgaria & . & . & 3.47 \\
\hline Canada & 4.45 & 5.03 & 5.55 \\
\hline Chile & 4.56 & 4.56 & 4.16 \\
\hline China & 3.47 & 3.31 & 3.45 \\
\hline Colombia & 3.36 & 3.97 & 3.42 \\
\hline Costa Rica & . & . & 3.87 \\
\hline Czech Republic & 2.9 & 2.86 & 2.9 \\
\hline Denmark & 5.27 & 5.79 & 6 \\
\hline Ecuador & . & . & 3.5 \\
\hline Egypt & 3.42 & 3.81 & 3.77 \\
\hline El Salvador & . & . & 3.7 \\
\hline Finland & 4.58 & 5.26 & 5.53 \\
\hline France & 3.87 & 4.69 & 5.17 \\
\hline Germany & 4.35 & 5.8 & 5.24 \\
\hline Greece & 3.46 & 3.5 & 3.41 \\
\hline Hong Kong & 4.17 & 4.32 & 3.94 \\
\hline Hungary & 3.36 & 4.04 & 3.81 \\
\hline Iceland & 3.89 & 4.53 & 4 \\
\hline India & 2.49 & 3.42 & 3.53 \\
\hline Indonesia & 2.82 & 3.33 & 3.56 \\
\hline Ireland & 4.4 & 5.58 & 5.19 \\
\hline Israel & 3.48 & 4.08 & 4.39 \\
\hline Italy & 2.92 & 3.88 & 4.38 \\
\hline Japan & 4.85 & 5.05 & 5.26 \\
\hline Jordan & 3.37 & 3.58 & 3.78 \\
\hline South Korea & 3.81 & 3.73 & 4.1 \\
\hline Luxembourg & 5.5 & 5.5 & 6.22 \\
\hline Malaysia & 3.69 & 3.65 & 3.42 \\
\hline Mauritius & . & . & 3.68 \\
\hline Mexico & 3.14 & 3.49 & 3.54 \\
\hline Netherlands & 4.63 & 4.62 & 5.2 \\
\hline New Zealand & 5.3 & 5.52 & 5.4 \\
\hline Norway & 4.08 & 4.67 & 4.24 \\
\hline
\end{tabular}




\begin{tabular}{lccc}
\hline Peru & 3.61 & 3.79 & 3.99 \\
Philippines & 2.79 & 3.32 & 3.48 \\
Poland & 3.46 & 4.48 & 3.88 \\
Portugal & 3.71 & 4.52 & 4.37 \\
Russia & 2.35 & 3.36 & 3.38 \\
Singapore & 5.1 & 5.54 & 5.58 \\
Slovakia &. & 3.25 & 3.47 \\
South Africa & 3.76 & 3.87 & 3.74 \\
Spain & 3.64 & 4.42 & 4.68 \\
Sweden & 4.35 & 5.48 & 5.58 \\
Switzerland & 4.8 & 5.3 & 4.67 \\
Taiwan & 3.1 & 3.42 & 3.18 \\
Thailand & 4.24 & 3.25 & 3.29 \\
Turkey & 3 & 4.26 & 3.58 \\
Ukraine &. & 3.9 & 4.56 \\
United Kingdom & 4.47 & 5.64 & 5.85 \\
United States & 4.63 & 5.13 & 5.64 \\
Venezuela & 2.81 & 3.04 & 3.3 \\
Vietnam &. & 5.92 & 6.77 \\
Zimbabwe &. & 3.93 & 3.8 \\
\hline
\end{tabular}


Appendix C: Sample Distribution by Country for the Insider Trading Law Enforcement Test

\begin{tabular}{|c|c|c|c|}
\hline Country & \# years & $\begin{array}{c}\text { First year of } \\
\text { data }\end{array}$ & $\begin{array}{c}\text { Last year of } \\
\text { data }\end{array}$ \\
\hline Argentina & 8 & 1994 & 2001 \\
\hline Australia & 8 & 1994 & 2001 \\
\hline Belgium & 8 & 1994 & 2001 \\
\hline Brazil & 8 & 1994 & 2001 \\
\hline Canada & 8 & 1994 & 2001 \\
\hline China & 2 & 2000 & 2001 \\
\hline France & 8 & 1994 & 2001 \\
\hline Germany & 8 & 1994 & 2001 \\
\hline Hong Kong & 8 & 1994 & 2001 \\
\hline Italy & 8 & 1994 & 2001 \\
\hline Japan & 8 & 1994 & 2001 \\
\hline Malaysia & 5 & 1997 & 2001 \\
\hline Mexico & 8 & 1994 & 2001 \\
\hline Netherlands & 8 & 1994 & 2001 \\
\hline New Zealand & 7 & 1995 & 2001 \\
\hline Singapore & 8 & 1994 & 2001 \\
\hline South Africa & 7 & 1995 & 2001 \\
\hline South Korea & 7 & 1995 & 2001 \\
\hline Spain & 8 & 1994 & 2001 \\
\hline Sweden & 8 & 1994 & 2001 \\
\hline Switzerland & 8 & 1994 & 2001 \\
\hline Taiwan & 2 & 2000 & 2001 \\
\hline United Kingdom & 8 & 1994 & 2001 \\
\hline United States & 8 & 1994 & 2001 \\
\hline Venezuela & 8 & 1994 & 2001 \\
\hline Total & 182 & & \\
\hline
\end{tabular}

